In cooperation with the Medina County Health Department

\title{
Assessment of the Use of Selected Chemical and Microbiological Constituents as Indicators of Wastewater in Curtain Drains From Home Sewage- Treatment Systems in Medina County, Ohio
}

Scientific Investigations Report 2006-5183 


\section{Assessment of the Use of Selected Chemical and Microbiological Constituents as Indicators of Wastewater in Curtain Drains From Home Sewage-Treatment Systems in Medina County, Ohio}

By Denise H. Dumouchelle

In cooperation with the Medina County Health Department

Scientific Investigations Report 2006-5183

U.S. Department of the Interior

U.S. Geological Survey 


\section{U.S. Department of the Interior DIRK KEMPTHORNE, Secretary \\ U.S. Geological Survey \\ P. Patrick Leahy, Acting Director}

\section{U.S. Geological Survey, Reston, Virginia: 2006}

For product and ordering information:

World Wide Web: http://www.usgs.gov/pubprod

Telephone: 1-888-ASK-USGS

For more information on the USGS--the Federal source for science about the Earth, its natural and living resources, natural hazards, and the environment:

World Wide Web: http://www.usgs.gov

Telephone: 1-888-ASK-USGS

Any use of trade, product, or firm names is for descriptive purposes only and does not imply endorsement by the U.S. Government.

Although this report is in the public domain, permission must be secured from the individual copyright owners to reproduce any copyrighted materials contained within this report.

Suggested citation:

Dumouchelle, D.H, 2006, Assessment of the use of selected chemical and microbiological constituents as indicators of wastewater in curtain drains from home sewage-treatment systems in Medina County, Ohio: U.S. Geological Survey Scientific Investigations Report 2006-5183, 20 p. 


\section{Contents}

Abstract Introduction
Purpose and Scope
Description of Home Sewage-Treatment Systems
Selection of Constituents for Study
Methods of Data Collection and Analysis
Chemical Constituents
Occurrence of Chemical and Microbiological Constituents
$\quad$ Chutrients
$\quad$ Chlomide and Bromide
$\quad$ Colide
E. coli Bacteria

\section{Figures}

1. Map showing location of sampled home sewage-treatment systems ……………........ 2

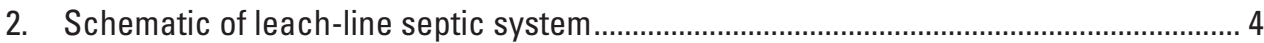

3. Construction sketches of gravel leach trench, gravelless leach trench, and

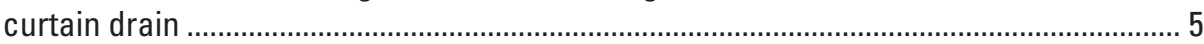

4. Diagram showing design of the evaporation-transpiration-absorption (ETA) system used in Medina County, Ohio ....................................................................................... 6

5. Photographs showing typical sampling points at curtain drains in Medina

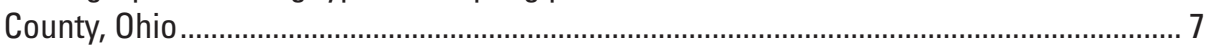

6. Graph showing relation of chloride concentration to chloride-bromide ratios for water from home sewage-treatment systems (HSTSs), HSTS curtain drain, and domestic-supply wells, Medina County, Ohio

7. Example of results of rep-PCR analysis showing six isolates and multiple measurements of a single isolate, demonstrating the reproducibility of results 


\section{Tables}

1. Site information for home sewage-treatment systems sampled in Medina County, Ohio

2. Results of analyses of samples from wells and home sewage-treament systems in Medina County, Ohio.

3. Chloride/bromide ratios in samples collected from home sewage-treatment system, associated curtain drains, and two residential wells in Medina County, Ohio

4. Results of analyses of bacteria and coliphage in samples from wells and home sewage-treatment systems in Medina County, Ohio.

5. Sites and numbers of isolates in those operational taxonomic units (OTU) found from more than one source from samples in Medina County, Ohio.

6. Summary of the utility of indicators used in this study for indicating the movement of partially untreated wastewater from home sewage-treatment systems to associated curtain drain.

\section{Conversion Factors}

\begin{tabular}{lll}
\hline Multiply & By & To obtain \\
\hline & Length & \\
\hline inch (in.) & 25.4 & millimeter $(\mathrm{mm})$ \\
foot (ft) & 0.3048 & meter (m) \\
\hline
\end{tabular}

Specific conductance is given in microsiemens per centimeter at 25 degrees Celsius $\left(\mu \mathrm{S} / \mathrm{cm}\right.$ at $\left.25^{\circ} \mathrm{C}\right)$.

Concentrations of chemical constituents in water are given either in milligrams per liter (mg/L) or micrograms per liter ( $\mu \mathrm{g} / \mathrm{L})$.

Concentrations of bacteria in water are given in colonies per 100 milliliters (col/100 mL).

Concentrations of coliphage in water are given in plaques per 100 milliliters (plaques/100 mL). 


\title{
Assessment of the Use of Selected Chemical and Microbiological Constituents as Indicators of Wastewater in Curtain Drains From Home Sewage-Treatment Systems in Medina County, Ohio
}

\author{
By Denise H. Dumouchelle
}

\section{Abstract}

Many home sewage-treatment systems (HSTS) in Ohio use curtain or perimeter drains to depress the level of the subsurface water in and around the systems. These drains could possibly intercept partially untreated wastewater and release potential pathogens to ground-water and surface-water bodies. The quality of water in curtain drains from two different HSTS designs in Medina County, Ohio, was investigated using several methods. Six evaporation-transpiration-absorption (ETA) and five leach-line (LL) systems were investigated by determining nutrient concentrations, chloride/bromide ratios $(\mathrm{Cl} / \mathrm{Br})$, Escherichia coli (E. coli) concentrations, coliphage genotyping, and genetic fingerprinting of $E$. coli. Water samples were collected at 11 sites and included samples from curtain drains, septic tanks, and residential water wells.

Nitrate concentrations in the curtain drains ranged from 0.03 to $3.53 \mathrm{mg} / \mathrm{L}$ (milligrams per liter), as $\mathrm{N}$. Concentrations of chloride in 10 of the 11 curtain drains ranged from 5.5 to $21 \mathrm{mg} / \mathrm{L}$; the chloride concentration in the eleventh curtain drain was $340 \mathrm{mg} / \mathrm{L}$. Bromide concentrations in 11 curtain drains ranged from 0.01 to $0.22 \mathrm{mg} / \mathrm{L}$. $\mathrm{Cl} / \mathrm{Br}$ ratios ranged from 86 to 2,000. F-specific coliphage were not found in any curtain-drain samples. Concentrations of E. coli in the curtain drains ranged from 1 to 760 colonies per 100 milliliters.

The curtain-drain water-quality data were evaluated to determine whether HSTS-derived water was present in the curtain drains. Nutrient concentrations were too low to be of use in the determination. $\mathrm{The} \mathrm{Cl} / \mathrm{Br}$ ratios appear promising. Coliphage was not detected in the curtain drains, so genotyping could not be attempted. E. coli concentrations in the curtain drains were all less than those from the corresponding HSTS; only one sample exceeded the Ohio secondary-contact water-quality standard. The genetic fingerprinting data were inconclusive because multiple links between unrelated sites were found.

Although the curtain-drain samples from the ETA systems showed somewhat more evidence of the presence of HSTS water than did the LL systems, most of the approaches were inconclusive by themselves. The best evidence of HSTS water, from the $\mathrm{Cl} / \mathrm{Br}$ ratios, indicates that the water in 10 of the 11 curtain drains, at both HSTS types, was a mixture of dilute ground water and HSTS-derived water; the 11th drain also show some effects of the HSTS, although road saltaffected water may be present. Therefore, it appears that there is no difference between the ETA and LL systems with respect to the water quality in curtain drains.

\section{Introduction}

Onsite or home sewage-treatment systems (HSTSs) are widely used in many areas of Ohio. The soils in Ohio are commonly unsuitable for traditional leach-line (LL) systems (Mancl and Slater, 2001), and as a result, various HSTS designs are used in the State. Many of these systems involve curtain drains, which are perforated pipes installed in trenches around the perimeter of the HSTS leaching area. These drains are typically 5 to $10 \mathrm{ft}$ from and not connected to the HSTS. The drains are intended to depress the shallow ground water in and around an HSTS. However, there are concerns that these drains could release partially treated wastewater and potential pathogens to ground-water and surface-water bodies.

A conventional LL system consists of a septic tank and a series of perforated pipes that discharge the wastewater to soil for treatment. Another type of HSTS, one that requires less land than an LL system, is the evaporation-transpirationabsorption (ETA) system. ETA systems are being used in a few counties in Ohio. The ETA system consists of a moundcovered trench with trees and other plants on the mound above the trench. The ETA design is considered an alternative or experimental system in Ohio, and the performance of these systems in clay-rich soils is not well documented. Approximately 1,200 ETA systems, with curtain drains, have been installed in Medina County, Ohio.

The U.S. Geological Survey (USGS), in cooperation with the Medina County Health Department (MCHD), sampled 
water from curtain drains from ETA systems and LL systems to obtain a better understanding of whether wastewater migrates from either HSTS design to the curtain drains. The objectives of the study were to evaluate several approaches to test for the presence of HSTS-derived water in curtain drains, to compare the approaches, and to describe the results with respect to two types of HSTS. This study builds on a series of previous USGS studies (Dumouchelle and Stoeckel, 2005; Jagucki and Darner, 2001; multiple references in Stoeckel, 2005) involving water quality or microbiological data as lines of evidence in identifying sources of contamination.

\section{Purpose and Scope}

This report presents data and results from the study described previously. The study area was Medina County, in northeastern Ohio (fig. 1). Water samples were collected at 11 HSTS sites in late June 2004. The samples were collected from curtain drains, septic tanks, and two residential water wells. Samples were analyzed for nutrients, chloride, bromide, coliphage, and Escherichia coli (E. coli) bacteria. Six ETA and five LL systems were investigated.

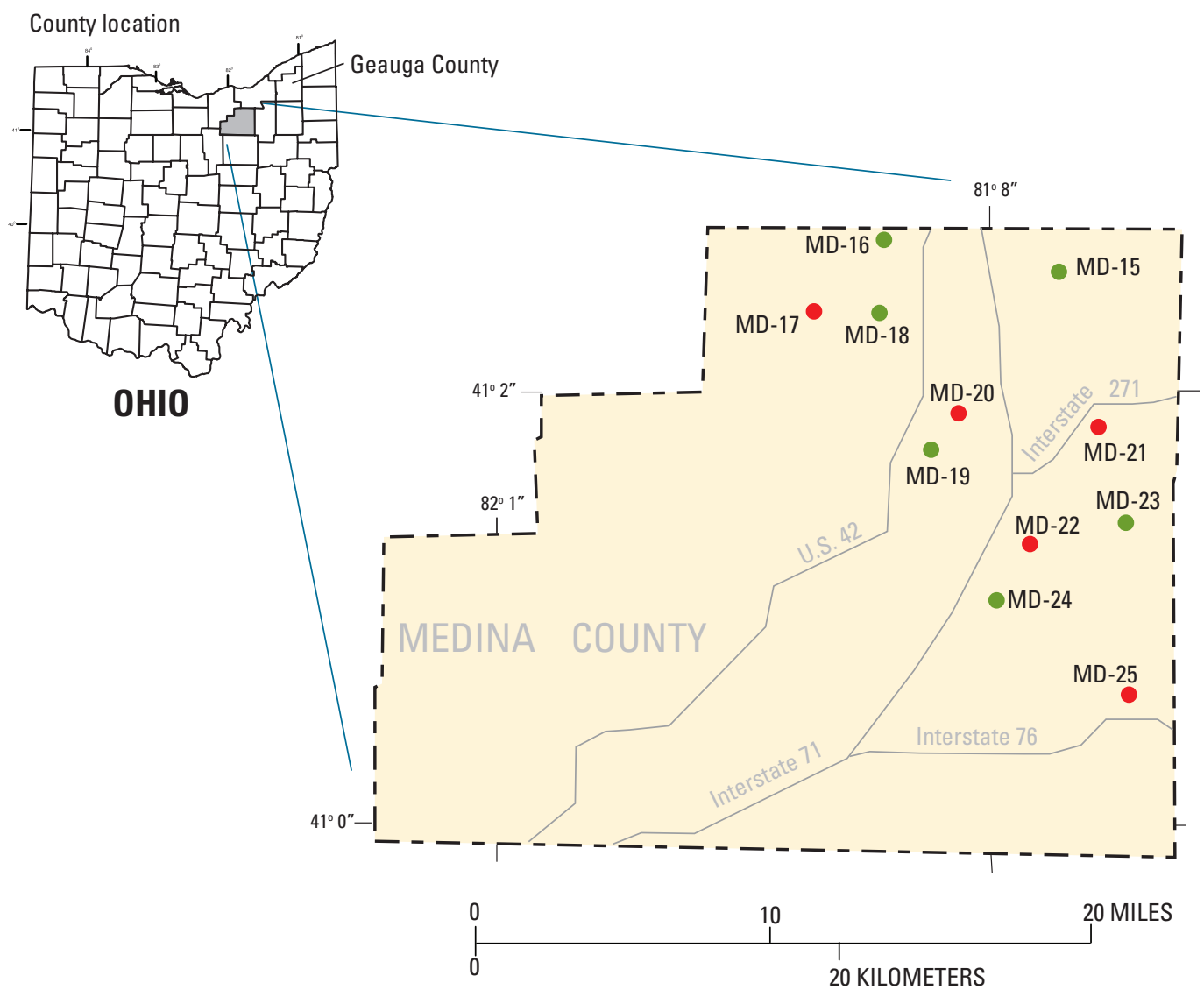

EXPLANATION

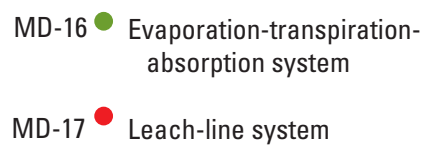

Figure 1. Location of sampled home sewage-treatment systems. 


\section{Description of Home Sewage-Treatment Systems}

Medina County has an estimated (2004) population of more than 165,000 people (Ohio Department of Development, 2005). About 31 percent of households in the county (more than 18,000) use HSTSs. Most of the soils in the county have some limitations with respect to the use of an HSTS, such as poor drainage, poor permeability, and high water tables (near land surface). The soils surrounding the HSTSs investigated in this study have all been rated as having severe limitations for an HSTS for one or more of these reasons (Hayhurst and others, 1977). Eleven HSTSs of two designs (LL or ETA) were investigated (fig. 1, table 1). Both designs incorporated curtain drains intended to depress shallow ground water. Curtain drains are not connected to the HSTS, and usually drain by gravity to a low area or ditch.

The five LL systems examined for this study consisted of either a septic tank or an aeration unit (table 1), followed by a diverter box that routed wastewater flow to one of two leaching-tile fields (fig. 2). The tile fields consisted of either a perforated pipe within a gravel-filled trench or a similar pipe, wrapped in a geotextile, within a gravelless trench (fig. $3 A, B)$. Curtain drains are constructed in a similar manner as the leach lines (fig. 3C). For all LL systems in this study, the curtain drain surrounded the leach field on all four sides and discharged through a single outlet pipe (fig. 2). The approximate average distance between the outermost leach tile and the curtain-drain tile ranged from $7.5 \mathrm{ft}$ to $11.8 \mathrm{ft}$ (table 1).

Six ETA systems were examined in this study. The ETA design consists of an aeration unit that discharges to a single leach line that is placed at the top of a gravel-lined trench (fig. 4). A mound of topsoil is placed above the trench, the sides of the mound are compacted soil or clay, and evergreen trees and thick grass are planted within the topsoil along the top of the mound. For the ETA systems in this study, the curtain drains were installed along the longitudinal sides of the mound and around at least one end of the mound. The approximate average distance between the mound and the curtain-drain tile ranged from $7 \mathrm{ft}$ to $9.5 \mathrm{ft}$ (table 1).

Table 1. Site information for home sewage-treatment systems sampled in Medina County, Ohio.

[LL, leach-line system; ETA, evaporation-transpiration-absorption system]

\begin{tabular}{|c|c|c|c|c|c|c|}
\hline \multirow{2}{*}{$\begin{array}{c}\begin{array}{c}\text { Site } \\
\text { name }\end{array} \\
\text { MD-15 }\end{array}$} & \multicolumn{2}{|c|}{$\begin{array}{l}\text { System type } \\
\text { and year of } \\
\text { installation }\end{array}$} & \multirow{2}{*}{$\begin{array}{c}\begin{array}{c}\text { Soil series } \\
\text { (Hayhurst and } \\
\text { others, 1977) }\end{array} \\
\text { Mahoning Silt Loam }\end{array}$} & \multirow{2}{*}{$\begin{array}{c}\text { Approximate dis- } \\
\text { tance from system } \\
\text { to curtain drain, } \\
\text { in feet }\end{array}$} & \multirow{2}{*}{$\begin{array}{c}\text { Curtain-drain sample location } \\
\text { Flow in gravel, pool }\end{array}$} & \multirow{2}{*}{$\begin{array}{c}\begin{array}{l}\text { Approximate mini- } \\
\text { mum distance from } \\
\text { road to drain, in feet }\end{array} \\
351\end{array}$} \\
\hline & ETA & 2003 & & & & \\
\hline MD-16 & ETA & 1998 & Mahoning Silt Loam & 8 & From pipe & 306 \\
\hline MD-17 & LL & 2003 & Mahoning Silt Loam & 8 & From pipe & 300 \\
\hline MD-18 & ETA & 2002 & Mahoning/Ellsworth & 7.5 & Pool below pipe & 129 \\
\hline MD-19 & ETA & 2003 & Rittman Silt Loam & $8.5 / 9.5$ & From pipe & 225 \\
\hline MD-22 & LL & 2003 & Wadsworth/Rittman & 7.7 & Pool below pipe & 312 \\
\hline $\mathrm{MD}-23^{\mathrm{b}}$ & ETA & 2002 & Fitchville/Glenford & 7.2 & From pipe at lift pump & 33 \\
\hline MD-24 & ETA & 2004 & Ellsworth Silt Loam & 7 & From pipe & 168 \\
\hline MD-25a, & LL & 1998 & Canfield/Ravenna & 7.5 & From pipe & 276 \\
\hline
\end{tabular}

\footnotetext{
${ }^{a}$ These systems used a septic tank rather than an aerator unit.
}

${ }^{\mathrm{b}}$ Residential wells sampled at these locations. 


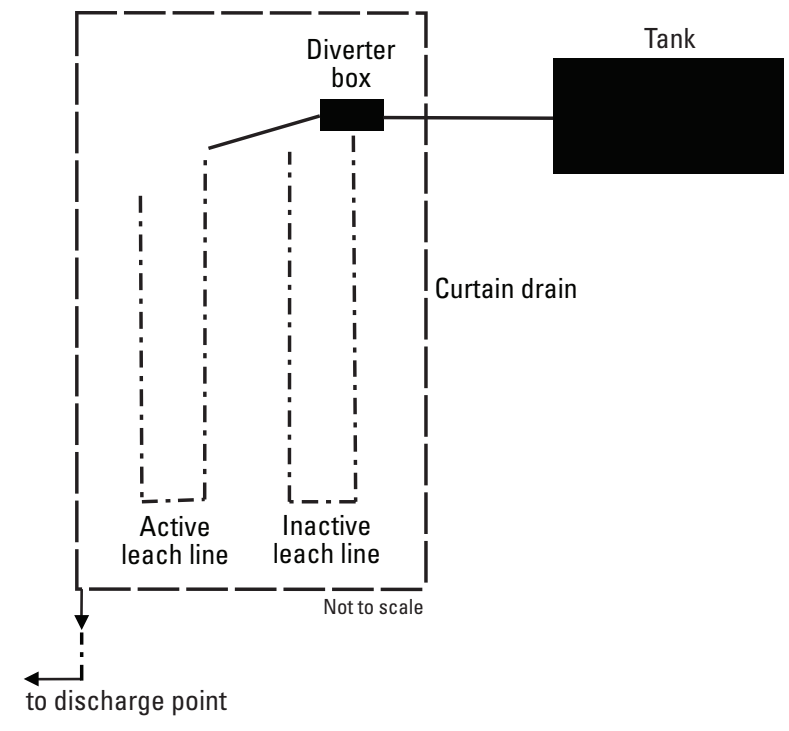

Figure 2. Schematic of leach-line septic system.

\section{Selection of Constituents for Study}

Samples of water collected from the curtain drains and the HSTSs were analyzed for a selected suite of chemical and microbiological constituents. The presence, or absence, of these constituents in the samples provided multiple lines of evidence as to the source of the water; that is, whether or not it was derived from the HSTSs. The chemical constituents of interest in this study were nutrients, chloride, and bromide; the microbiological constituents of interest were coliphage and E. coli bacteria.

Nutrients are ions or organic compounds that contain nitrogen or phosphorus. Nitrogen concentrations are of concern with respect to human-health issues; for drinking water, the Maximum Contaminant Level (MCL) established for nitrite is $1 \mathrm{mg} / \mathrm{L}$ (as N), and that for nitrate is $10 \mathrm{mg} / \mathrm{L}$ (as N) (U.S. Environmental Protection Agency, 2004). Nitrogen fertilizers and sewage are common sources of nitrogen contamination in waters. Nitrate, the main form of nitrogen in ground water, is very mobile. Nitrogen from HSTSs generally enters the soil as organic nitrogen, nitrate, or ammonia. In the soil, above the water table, oxidation converts the various nitrogen forms to nitrate, and bacterial systems or redox reactions convert the nitrate to nitrogen and nitrous oxide. Nitrogen and nitrous oxide can be lost to the atmosphere and, if dissolved, are not harmful in drinking water (Freeze and Cherry, 1979, p. 413-415).

The ratio of chloride to bromide $(\mathrm{Cl} / \mathrm{Br})$ concentrations has been used to identify or confirm sources of ground-water contamination (Davis and others, 1998; Eberts and others,
1990; Jagucki and Darner, 2001; Thomas, 2000). These constituents can be useful because they are both soluble in water and conservative; that is, they are not prone to adsorption to sediment or redox alterations (Hem, 1989; Davis and others, 1998).

Microbiological constituents of interest in this study were coliphage and $E$. coli. Coliphage are viruses that infect bacteria, including E. coli. Coliphage are an indicator of fecal contamination and are sometimes used as a surrogate for the subsurface transport of fecal-origin human viruses. Samples from HSTSs were analyzed for both somatic and F-specific coliphage. Genotyping analysis of coliphage, to determine human as opposed to nonhuman sources, can be done only on F-specific RNA-based coliphage, so these were of most interest for detection of the transport of any partially treated wastewater between an HSTS and curtain drains. E. coli is itself a longstanding indicator of fecal contamination, although $E$. coli detection alone does not address the source of the contamination. However, repetitive DNA element polymerase chain reaction (rep-PCR) has been used to indicate the source of $E$. coli (Dombeck and others, 2000; Carson and others, 2003).

\section{Methods of Data Collection and Analysis}

Sites were selected by the MCHD to represent a combination of ETA and LL HSTSs throughout the county. Water samples were collected by the USGS at 11 properties. Samples were collected from curtain-drain outfalls and within the HSTSs; samples also were collected from the faucets in two homes supplied with water from their own wells. The wells were completed in sandstone, with open intervals from 62 to $100 \mathrm{ft}$ (below ground) and 35 to $78 \mathrm{ft}$.

Most of the curtain-drain outfalls (fig. 5) were partly buried and (or) produced minimal flows; so, in some cases, the area beneath the outfall pipe was dug out to create a pool for sample collection. When possible, samples were collected from the outfall by placing a collection bottle underneath the pipe or by using a peristaltic pump and sterile tubing from within the pipe. Other curtain-drain samples were collected from a pool near the outfall discharge with a peristaltic pump and sterile tubing (table 1). Samples from the HSTSs were collected post aerator (when present), either from within the tank or from the diverter box using a peristaltic pump and sterile, weighted tubing. In addition, one known sample from surface scat ( $\mathrm{dog}$ ) was collected for E. coli analysis using methods described in Dumouchelle and Stoeckel (2005)

Replicate samples and one field blank were collected for quality control. These samples were analyzed to identify any variability in analytical results that might be associated with sample-collection or laboratory methods. 

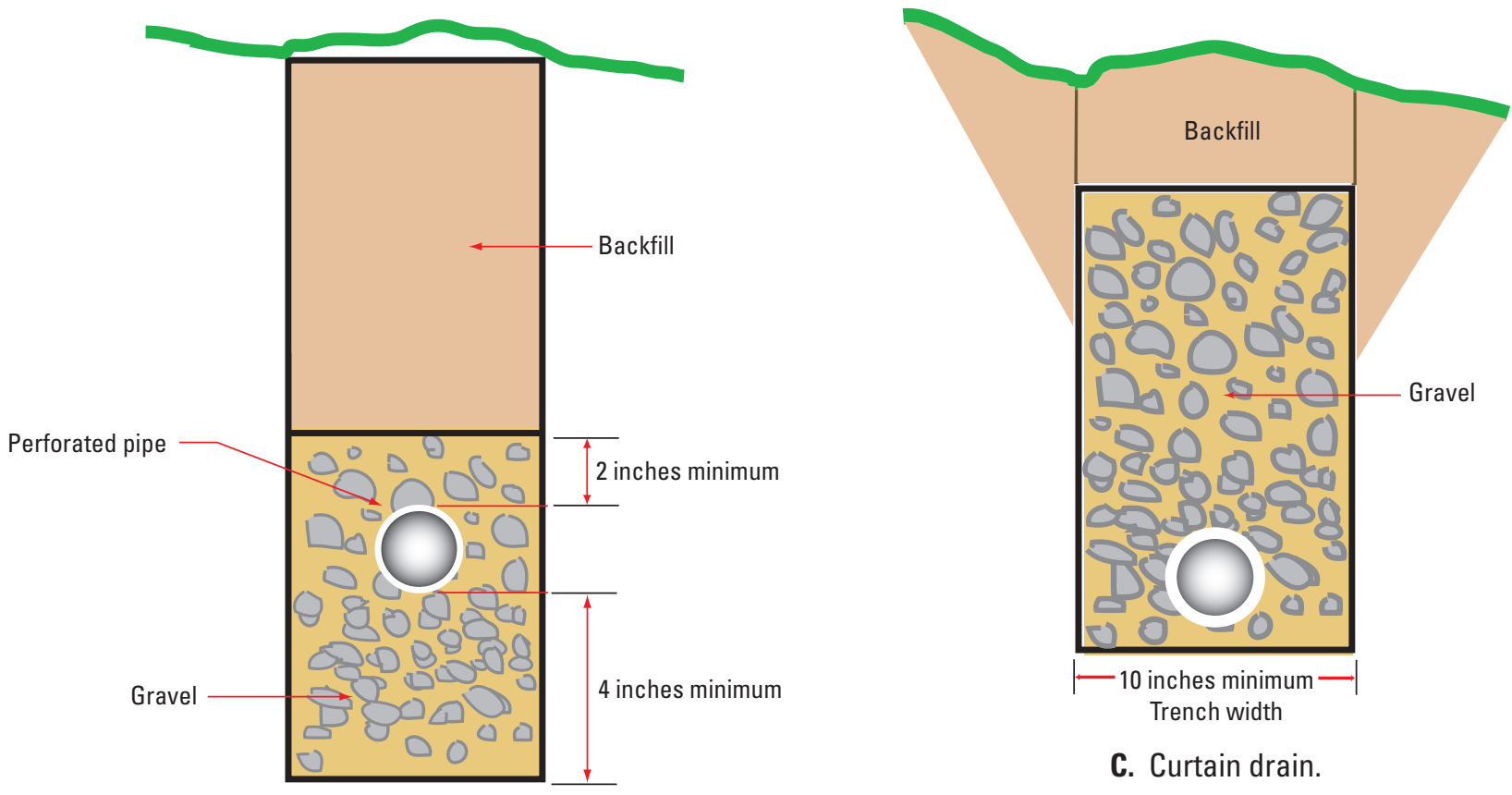

A. Gravel leach trench.

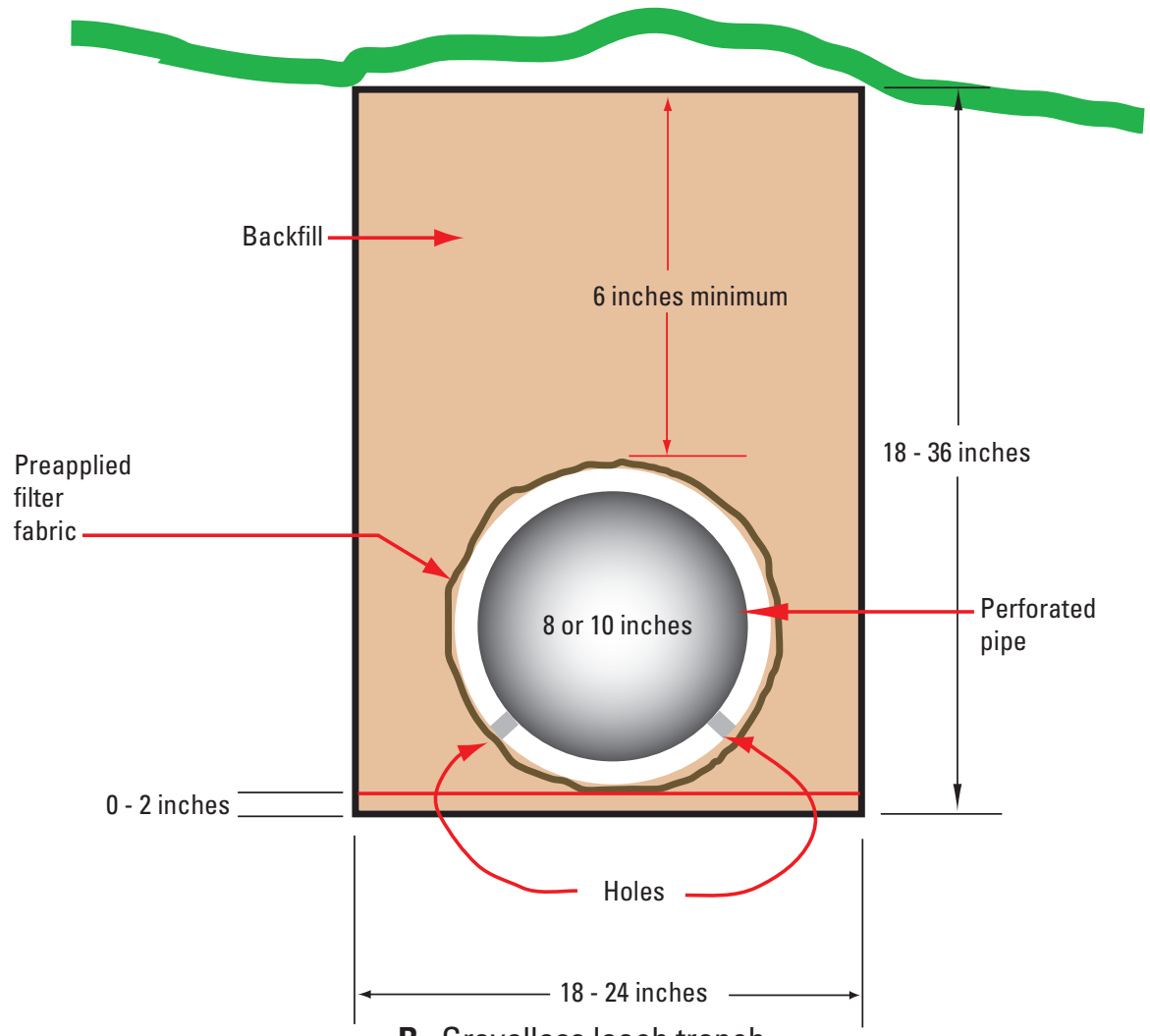

B. Gravelless leach trench.

Figure 3. Construction sketches: $A$, Gravel leach trench. $B$, Gravelless leach trench. $C$, Curtain drain. 


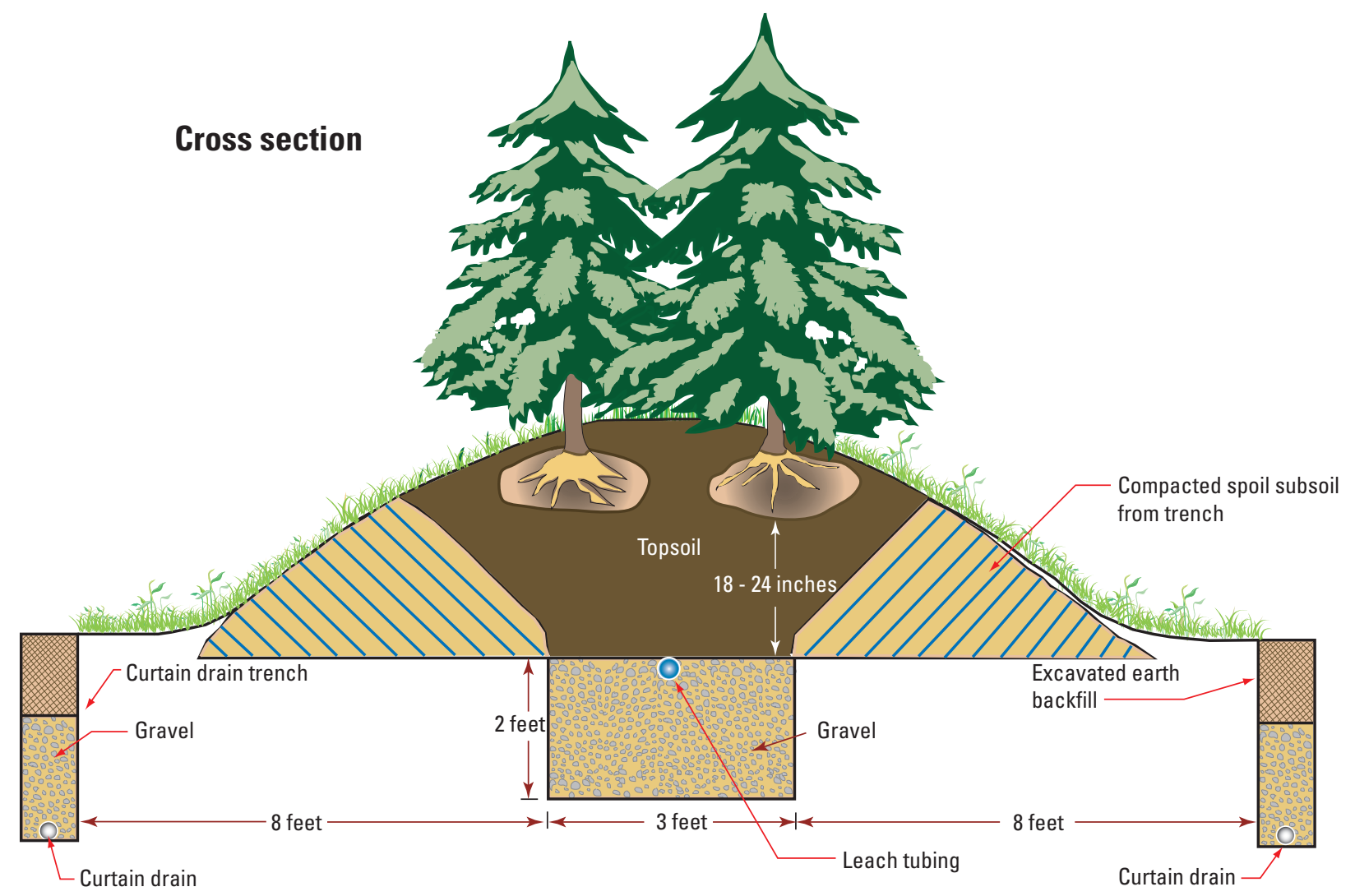

Schematic

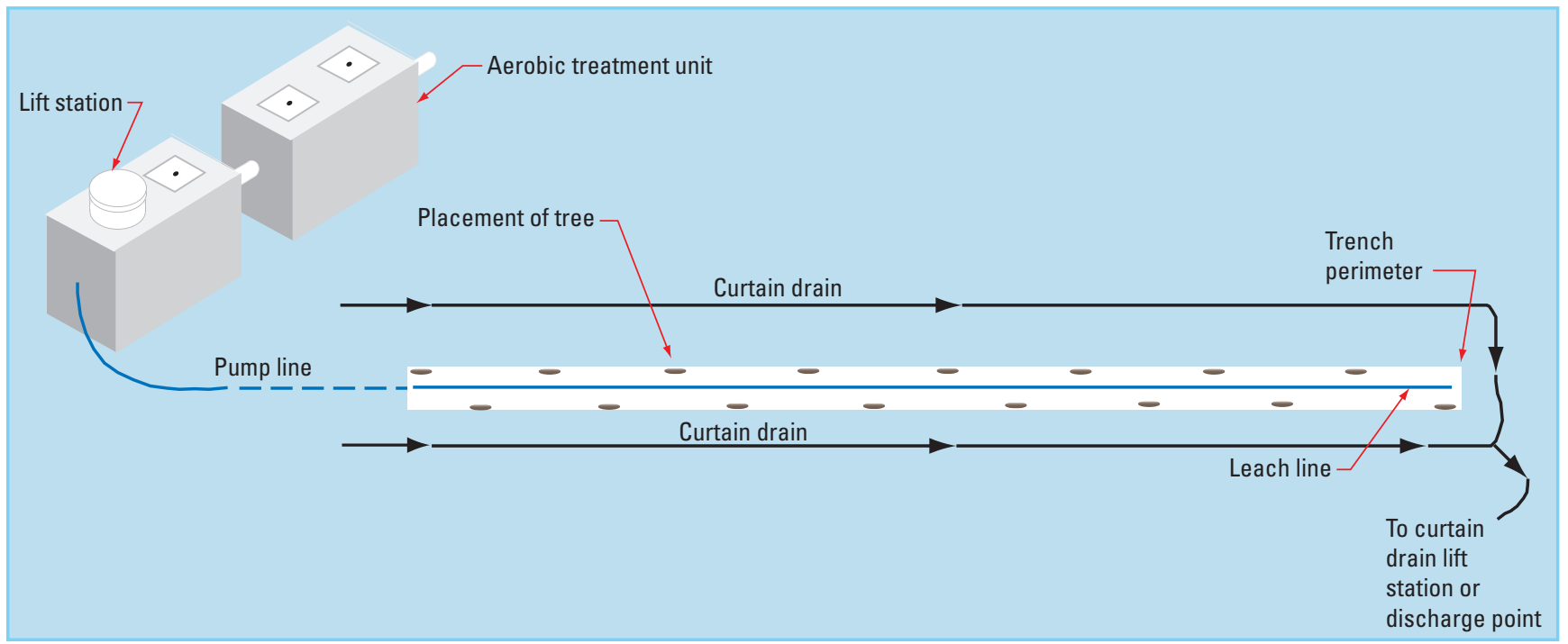

Figure 4. Diagram showing design of the evaporation-transpiration-absorption (ETA) system used in Medina County, Ohio 


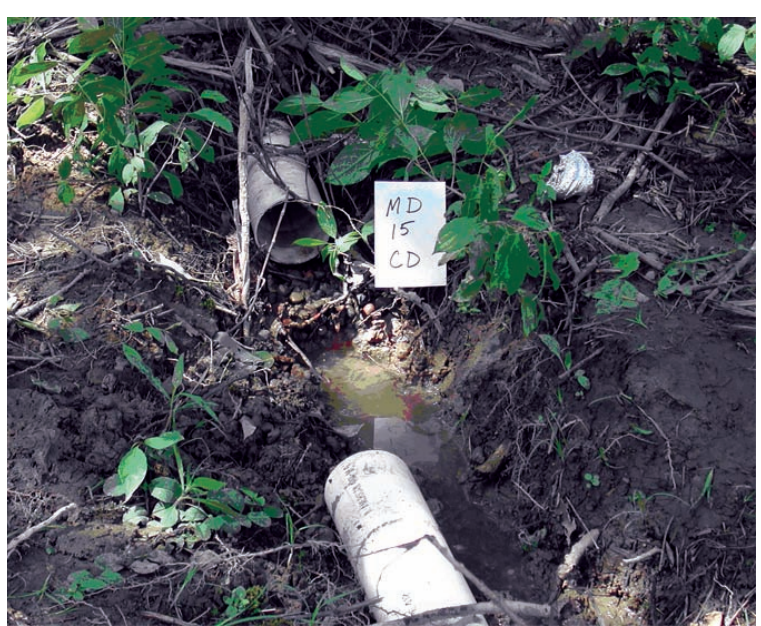

MD-15

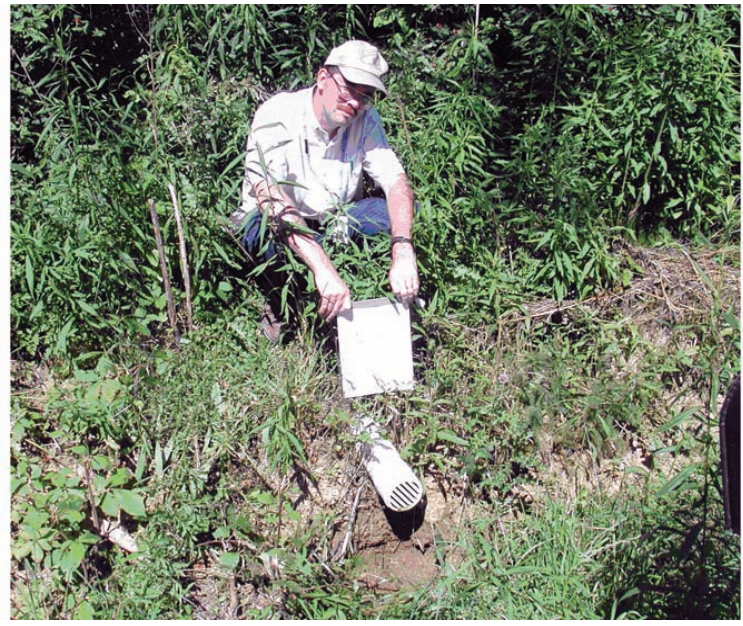

MD-23

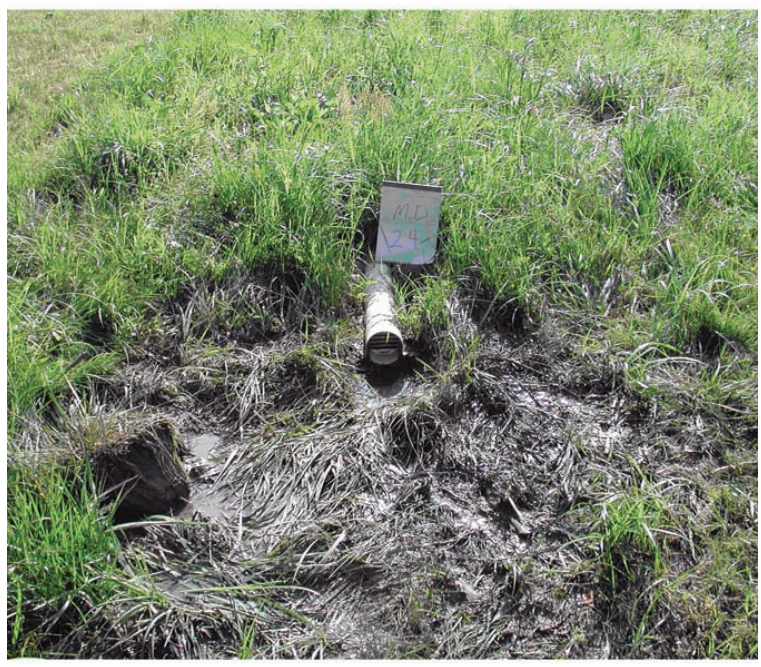

MD-24

Figure 5. Photographs showing typical sampling points at curtain drains in Medina County, Ohio.

\section{Chemical Constituents}

Water samples from the 11 curtain drains, 2 HSTSs, and 2 wells were analyzed for nutrients, chloride, and bromide. Samples were transferred from a common collection bottle to the analysis bottles by use of a peristaltic pump with an inline filter on the tubing. Sampling tubing was cleaned with nonphosphate detergent and deionized water, followed by sterilization in an autoclave. The samples were shipped to the USGS National Water-Quality Laboratory (NWQL) in Denver, Colo. The nutrient samples were analyzed for concentrations of ammonia, nitrite, nitrite plus nitrate, and orthophosphate (Fishman, 1993); the reporting limits, respectively, for these constituents were $0.04,0.008,0.06$, and $0.018 \mathrm{mg} / \mathrm{L}$. Nitrate concentrations were calculated by subtracting the concentration of nitrite from the concentration of nitrate plus nitrite. Nitrate and nitrite concentrations are reported as nitrogen (as N). Chloride analysis was done by ion-exchange chromatography (Fishman and Friedman, 1989) and at a reporting limit of $1 \mathrm{mg} / \mathrm{L}$. The bromide analysis was done by fluorescein colorimetry (Fishman and Friedman, 1989); the reporting limit for this method was $0.02 \mathrm{mg} / \mathrm{L}$. 
Two replicate samples were collected for analysis of nutrients, chloride, and bromide. Analytical results of the replicate samples were compared qualitatively with those of the field samples. The analytical results of the two sample sets were comparable (less than 5 percent difference) except those for one ammonia and one nitrite sample. The replicate ammonia analysis had a concentration of $0.057 \mathrm{mg} / \mathrm{L}$ as compared to less than $0.04 \mathrm{mg} / \mathrm{L}$. The replicate nitrite analysis had a concentration of less than $0.008 \mathrm{mg} / \mathrm{L}$ as compared to an estimated concentration of $0.005 \mathrm{mg} / \mathrm{L}$. A blank sample for analysis of nutrients, chloride, and bromide was collected by pumping blank water from the supply bottle into the sample bottle; no analytes were detected in the blank sample.

\section{Microbiological Constituents}

Water samples for microbiological analyses were collected with the same tubing used for chemical-constituents sampling. The tubing was cleaned with nonphosphate detergent and deionized water, followed by sterilization in an autoclave. Samples were analyzed for F-specific and somatic coliphage and E. coli. Selected E. coli isolates were subjected to rep-PCR analysis. These analyses were done in the USGS Ohio Water Microbiology Lab (OWML). Standard operating procedures, quality assurance, and quality control were followed and are detailed in Francy and others (2004) and Dumouchelle and Stoeckel (2005).

Water samples for analyses of F-specific and somatic coliphage were collected from the curtain drains and HSTSs at all 11 sites. The water from the HSTS was analyzed first, and the curtain-drain sample was analyzed only if F-specific coliphage was found in the HSTS sample. Samples were analyzed for coliphage by use of a quantitative, single-agar-layer method (U.S. Environmental Protection Agency, 2001). The intent was to genotype the coliphage if it was found in both the curtain drains and the HSTS. Coliphage genotyping methods are described in Hsu and others (1995) and Beekwilder and others (1996). Genotyping of F-specific coliphage can be used to help distinguish between human and nonhuman sources (Noble and others, 2003). Coliphage were not detected in any samples from curtain drains; therefore, no genotyping was done.

Water samples were plated to measure E. coli concentrations from the 11 curtain drains, 11 HSTSs, and 2 wells. Plating was done within 24 hours of sampling by use of the membrane filtration method with mTEC agar (U.S. Environmental Protection Agency, 2000). Nonstandard collection methods were required to obtain water samples from the HSTSs for E. coli analysis; these methods are described in Dumouchelle and Stoeckel (2005).

E. coli isolates, individual colonies isolated from the agar plate, were characterized by rep-PCR genomic analysis by a protocol similar to that reported by Rademaker and de Bruijn (1997), modified and standardized by Bacterial Barcodes (2004). Dumouchelle and Stoeckel (2005) describe these methods and related quality assurance/quality control procedures in detail. The rep-PCR method measures an index of genetic similarity but does not give information on species, so operational taxonomic units (OTU) were defined to assign genetically similar isolates to groups; isolates in an OTU had at least 96 percent genetic similarity by the procedures used. At least 10 percent of each OTU were tested to confirm that the OTU belonged to the species E. coli. Because of the clonal nature of $E$. coli populations (Whittam, 1989) and the diversity of $E$. coli reported in literature studies (Caugant and others, 1981; Johnson and others, 2004; Kariuki and others, 1999; McLellan, 2004; and Yang and others, 2004), all E. coli isolates belonging to the same OTU were assumed to have come from the same source.

Three replicate samples were collected for E. coli analysis; because of the wide range of variability in concentrations in microbiological analyses, quality-assurance analysis is frequently done with $\log _{10}$ transformed data (D.S. Francy, U.S. Geological Survey, oral commun., 2005). Two of the replicate analyses had less than 1 percent difference in $E$. coli counts between the (log-transformed) standard and replicate samples. The difference in the third (log-transformed) replicate analysis was only 10 percent, which is not considered significant (particularly because the replicate sample count of $16 \mathrm{col} / 100 \mathrm{~mL}$ was below the ideal range). One replicate sample for coliphage was analyzed. The standard sample had a count of 6,000 plaques $/ 100 \mathrm{~mL}$, and the replicate had a count of 8,000 plaques $/ 100 \mathrm{~mL}$, yielding a log-transformed difference of 18 percent. Given the difficulty in counting such a large number of plaques, the large percent difference is not unexpected.

\section{Occurrence of Chemical and Microbiological Constituents}

To determine whether HSTS-derived water was present in the curtain drains, data from several indicators were evaluated to provide multiple lines of evidence: the occurrence and concentrations of nutrient, chloride and bromide ratios, and E. coli; $\mathrm{Cl} / \mathrm{Br}$ ratios; genotyping of coliphage; and genetic fingerprinting of $E$. coli. Differences in the composition of water in the drains at ETA and LL systems were evaluated qualitatively.

\section{Nutrients}

In the curtain drains, ammonia concentrations ranged from 0.03 to $2.17 \mathrm{mg} / \mathrm{L}$; concentrations in the HSTS were 1.20 and $25.7 \mathrm{mg} / \mathrm{L}$; concentrations in both wells were less than $0.04 \mathrm{mg} / \mathrm{L}$ (table 2). Concentrations of orthophosphate were generally less than $0.02 \mathrm{mg} / \mathrm{L}$; the highest concentrations were in the HSTS at 4.37 and $4.39 \mathrm{mg} / \mathrm{L}$. In the curtain drains, nitrite concentrations ranged from 0.005 to $0.011 \mathrm{mg} / \mathrm{L}$; 


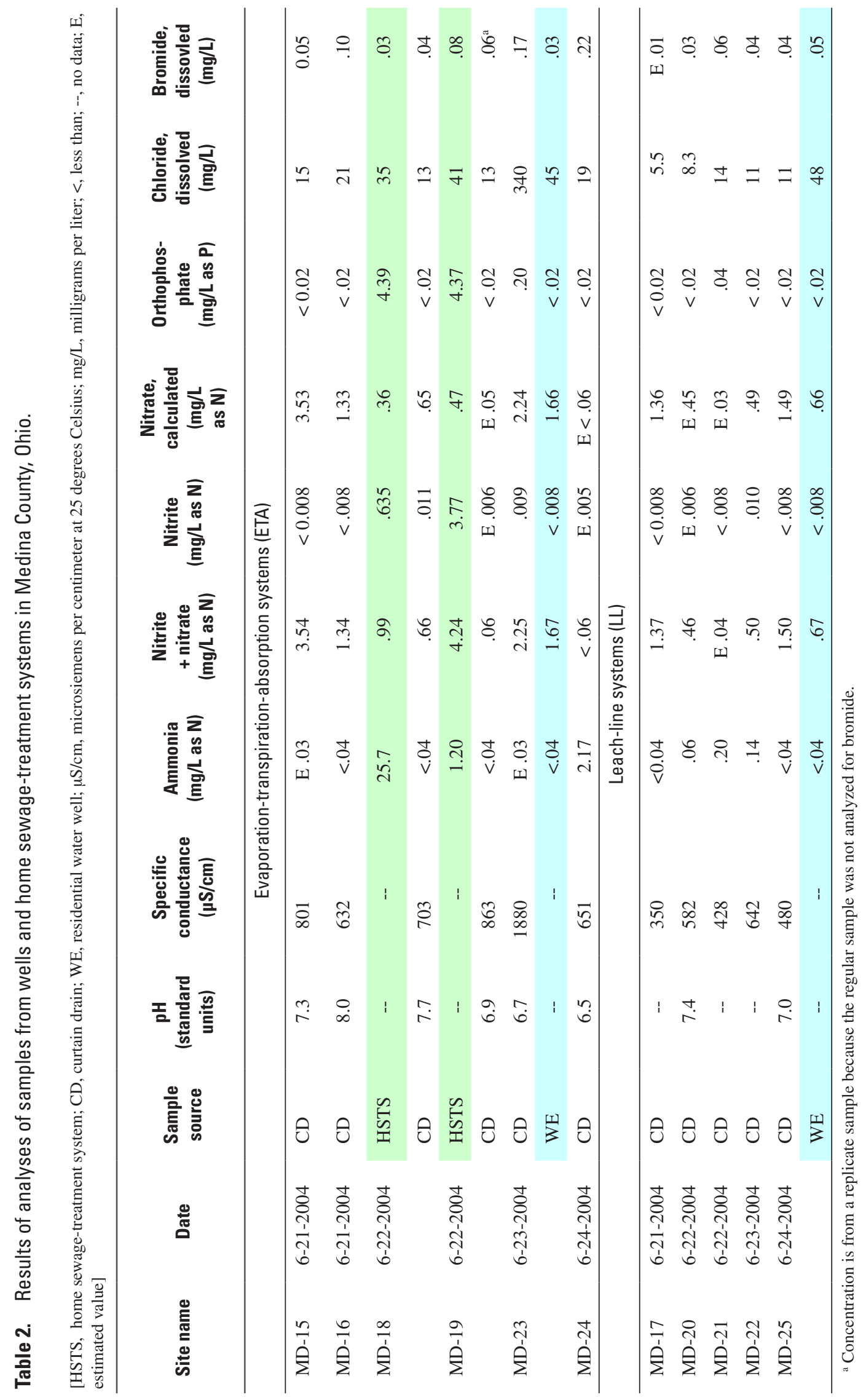


concentrations in the HSTS were 0.635 and $3.77 \mathrm{mg} / \mathrm{L}$; concentrations in the wells were less than $0.008 \mathrm{mg} / \mathrm{L}$. Calculated nitrate concentrations in the curtain drains ranged from 0.03 to $3.53 \mathrm{mg} / \mathrm{L}$; concentrations in the HSTS were 0.36 and 0.47 $\mathrm{mg} / \mathrm{L}$, and concentrations in the wells were 0.66 and 1.66 $\mathrm{mg} / \mathrm{L}$.

Baker and others (1989) analyzed 16,166 samples of water from private wells throughout Ohio. They considered nitrate concentrations ${ }^{1}$ of $0.3 \mathrm{mg} / \mathrm{L}$ (as N) or less as representative of background concentrations, concentrations of 3.1 to $10 \mathrm{mg} / \mathrm{L}$ (as N) as possibly indicating effects of human activity, and concentrations greater than $10 \mathrm{mg} / \mathrm{L}$ (as $\mathrm{N}$ ) as being most likely due to human activity. In the spring of 1987 and spring 1988, water samples from 182 private wells in Medina County were analyzed; 75 percent (136 wells) had nitrate concentrations less than $0.3 \mathrm{mg} / \mathrm{L} ; 7$ percent (13 wells) had concentrations between 3.0 and $10 \mathrm{mg} / \mathrm{L} ; 2$ percent (4 wells) had concentrations greater than $10 \mathrm{mg} / \mathrm{L}$ (Baker and others, 1989).

The highest concentration of nitrate detected in this study, $3.53 \mathrm{mg} / \mathrm{L}$ in a sample from the curtain drain at MD-15 (table 2), was well below the MCL of $10 \mathrm{mg} / \mathrm{L}$. Nitrate concentrations from curtain drains at the 6 ETA systems ranged from less than 0.05 to $3.53 \mathrm{mg} / \mathrm{L}$, with a median concentration of $0.99 \mathrm{mg} / \mathrm{L}$. Nitrate concentrations from curtain drains at $5 \mathrm{LL}$ systems ranged from 0.03 to $1.49 \mathrm{mg} / \mathrm{L}$, with a median concentration of $0.49 \mathrm{mg} / \mathrm{L}$.

In a similar study by the Ohio Department of Health (ODH), 28 samples were collected from 21 curtain drains (all LL systems) in 2 counties (J. Caudill, Ohio Department of Health, written commun., 2005). The ODH-reported nitrite plus nitrate concentrations ranged from less than 1 to 3.64 $\mathrm{mg} / \mathrm{L}$, with a median of $0.43 \mathrm{mg} / \mathrm{L}$. In comparison, the nitrite plus nitrate concentrations in curtain-drain samples from the Medina County LL systems ranged from 0.04 to $1.5 \mathrm{mg} / \mathrm{L}$, with a median of $0.5 \mathrm{mg} / \mathrm{L}$; concentrations in curtain-drain samples from the Medina County ETA systems ranged from less than 0.06 to $3.54 \mathrm{mg} / \mathrm{L}$, with a median of $1.0 \mathrm{mg} / \mathrm{L}$. Although the concentrations in curtain-drain samples from the Medina County ETA systems have a slightly larger range and higher median value than those in samples from the LL systems, the concentrations from the curtain drains at both systems were, with one exception, below the range that Baker and others (1989) thought indicative of possible anthropogenic effects.

Phosphorus, a component of sewage, is an essential nutrient for plant growth; phosphorus enrichment, however, can lead to algal blooms and eutrophication of water bodies. In water samples, orthophosphate is the most stable form of phosphorus. Phosphorus tends to precipitate out of solution, so dissolved phosphorus added to soils from an HSTS may not remain available for long periods (Hem, 1989). No standards

\footnotetext{
${ }^{1}$ Nitrite plus nitrate concentrations were referred to as "nitrate" in their study.
}

have been established for phosphorus in the Ohio Water Quality Standards; however, large-volume point-source discharges in the Lake Erie basin have a permit limit of $1.0 \mathrm{mg} / \mathrm{L}$ in the final effluent (Ohio Environmental Protection Agency, 2003a). Orthophosphate concentrations above the detection limit were found only in the HSTS samples at MD-18 and MD-19 (table 2). There were no meaningful differences between ETA and LL systems with respect to orthophosphate concentrations in curtain drains.

\section{Chloride and Bromide}

Concentrations of chloride in 10 of the 11 curtain drains sampled ranged from 5.5 to $21 \mathrm{mg} / \mathrm{L}$; the chloride concentration in the 11th curtain drain was $340 \mathrm{mg} / \mathrm{L}$ (table 2). Chloride concentrations in the samples from the HSTS were 35 and 41 $\mathrm{mg} / \mathrm{L}$ and from the water wells, 45 and $48 \mathrm{mg} / \mathrm{L}$. It should be noted that the homes at which the HSTS water samples were collected for the analyses of chloride and bromide used citysupplied water with an average chloride concentration of 20 parts per million (parts per million are roughly equivalent to milligrams per liter).

The bromide concentration in one curtain drain sample, MD-19, was not determined; fortunately, a replicate sample was collected at that site, so the results of the replicate analysis is reported. Bromide concentrations in the 11 curtain drains ranged from 0.01 to $0.22 \mathrm{mg} / \mathrm{L}$. Bromide concentrations in the HSTSs were 0.03 and $0.08 \mathrm{mg} / \mathrm{L}$; concentrations in the wells were 0.03 and $0.05 \mathrm{mg} / \mathrm{L}$. Bromide analyses were not available for the city water supply.

\section{Chloride}

Chloride concentrations in sewage are frequently elevated relative to natural waters but the degree to which HSTS effluent affected the chloride concentrations in curtain drains in this study cannot be definitively determined. On the basis of data on chloride concentrations in septic effluent, road salt runoff, and background concentrations in ground water, however, it may be possible to identify some HSTS effects on the quality of water in the drains. Panno and others (2006) reported chloride concentrations in 29 samples from septic systems ranged 21 to $5,620 \mathrm{mg} / \mathrm{L}$; with a median concentration of 91 $\mathrm{mg} / \mathrm{L}$. The two samples collected from the septic tanks in this study had chloride concentrations of 35 and $41 \mathrm{mg} / \mathrm{L}$ (table 2), within the range reported by Panno and others (2006).

Elevated chloride concentrations also could result from road salt contamination. Panno and others (2006) reported chloride concentrations in 13 wells affected by road salt ranged from 44 to $416 \mathrm{mg} / \mathrm{L}$, which was similar to the range of chloride concentrations, 40 to $116 \mathrm{mg} / \mathrm{L}$, they reported in 3 wells affected by septic contamination. The highest chloride concentration detected in Medina County, $340 \mathrm{mg} / \mathrm{L}$, was in the sample from the curtain drain at MD-23. The HSTS is 
close to the road at MD-23, with the curtain drain as close as $33 \mathrm{ft}$ from the road (table 1). In addition, a water softener was known to be in use at the site. The relatively high chloride concentration could be the result of road salt or HSTS-derived water or a combination of both.

The curtain drains are not within material that would be considered an aquifer but rather in clay-rich, glacially derived soils. Background or reference chloride concentrations used for comparison should reflect such conditions. Dumouchelle and Stoeckel (2005) noted that reported chloride concentrations in glacial sediments in Ohio and southeastern Michigan ranged from 1.0 to $544 \mathrm{mg} / \mathrm{L}$, with the median values for datasets ranging from 4 to $79 \mathrm{mg} / \mathrm{L}$. Given these ranges, Dumouchelle and Stoeckel (2005) used a chloride concentration of $200 \mathrm{mg} / \mathrm{L}$ as a conservative indicator that water sampled from piezometers a few feet from HSTS leach lines was likely affected by HSTS effluent.

Although the range in and median concentrations of chloride in samples from the ETA system curtain drains (13 to $340 \mathrm{mg} / \mathrm{L} ; 17 \mathrm{mg} / \mathrm{L})$ were larger than those for the LL systems ( 5.5 to $14 \mathrm{mg} / \mathrm{L} ; 11 \mathrm{mg} / \mathrm{L}$ ), the concentrations in all but one of the samples were less than $22 \mathrm{mg} / \mathrm{L}$ (table 2). In the study by the ODH mentioned earlier (J. Caudill, Ohio Department of Health, written commun., 2005), chloride concentrations ranged from less than $5 \mathrm{mg} / \mathrm{L}$ to $2,380 \mathrm{mg} / \mathrm{L}$, with a median of $14 \mathrm{mg} / \mathrm{L}$. Considering the data from both studies, no difference could be determined between ETA and LL systems with respect to chloride concentrations.

\section{Bromide}

Bromide concentrations are naturally low; concentrations in rainwater and snow range from about 0.005 to $0.15 \mathrm{mg} / \mathrm{L}$ (Hem, 1989) and typically are about $0.02 \mathrm{mg} / \mathrm{L}$ in streams (Drever, 1988). The ranges of reported bromide concentrations for various sources of water overlap, making it difficult to use bromide itself as an indicator of the source of water. Bromide values can be useful in ratio with chloride values, however, because small changes in bromide concentrations can give rise to large variations in the $\mathrm{Cl} / \mathrm{Br}$ ratio.

The bromide concentrations in the ETA curtain-drain samples ranged from 0.04 to $0.22 \mathrm{mg} / \mathrm{L}$, with a median of $0.08 \mathrm{mg} / \mathrm{L}$. The concentrations in samples from the LL curtain drains ranged from 0.01 to $0.06 \mathrm{mg} / \mathrm{L}$, with a median of $0.04 \mathrm{mg} / \mathrm{L}$. Although the data are few and the concentrations low, samples from the ETA curtain drains seem to the have higher bromide concentrations.

\section{Chloride/Bromide Ratios}

The ratio of chloride to bromide concentrations has been used in several studies as an indicator of the presence of sewage. Several ranges for $\mathrm{Cl} / \mathrm{Br}$ ratios in sewage have been reported: 275-531(Behl and others, 1987, cited in
Table 3. Chloride/bromide ratios in samples collected from home-sewage treatment systems, associated curtain drains, and two residential wells in Medina County, Ohio.

[HSTS, home sewage-treatment system; CD, curtain drain; WE, residential water well]

\begin{tabular}{ccc}
\hline Site name & $\begin{array}{c}\text { Sample } \\
\text { source }\end{array}$ & $\begin{array}{c}\text { Chloride/bromide } \\
\text { ratio }\end{array}$ \\
\hline Evaporation-transpiration-absorption systems (ETA) \\
\hline MD-15 & CD & 300 \\
MD-16 & CD & 210 \\
MD-18 & HSTS & 1,200 \\
& CD & 330 \\
MD-19 & HSTS & 520 \\
& CD & $220^{\mathrm{a}}$ \\
MD-23 & CD & 2,000 \\
& WE & 1,500 \\
MD-24 & CD & 86 \\
\hline & Leach-line systems (LL) & \\
\hline MD-17 & CD & 550 \\
MD-20 & CD & 280 \\
MD-21 & CD & 230 \\
MD-22 & CD & 280 \\
MD-25 & CD & 280 \\
& WE & 960 \\
\hline
\end{tabular}

${ }^{a}$ Chloride/bromide ratio from analyses of replicate sample.

Thomas, 2000), 410-873 (Vengosh and Pankratov, 1998, cited in Thomas, 2000), 300-600 (Davis and others, 1998), and 64-5,404 (Panno and others, 2006). These ranges were used to define the "sewage box" in figure 6 indicating the range of ratios in sewage. The ranges of chloride concentrations in sewage were discussed previously. $\mathrm{The} \mathrm{Cl} / \mathrm{Br}$ ratios in the two samples from septic tanks in Medina County, 520 and 1,200 (table 3), fall within the sewage box in figure 6 .

The "road-salt" box (fig. 6) was defined by data from samples from ground water wells contaminated with road salt (Panno and others, 2006) rather than from samples of a pure solution. This road-salt box is also consistent with multiyear data from four road-salt/ground-water study sites in northcentral and northeast Ohio (Jones and Sroka, 1997). Davis and others (1998) noted that the water affected by halite dissolution (road salt) generally has $\mathrm{Cl} / \mathrm{Br}$ ratios in the range of 1,000 to 10,000 .

The two wells in Medina County, at sites MD-23 and MD-25, were sampled in this study to provide background water-quality data; however, the data from these wells were 


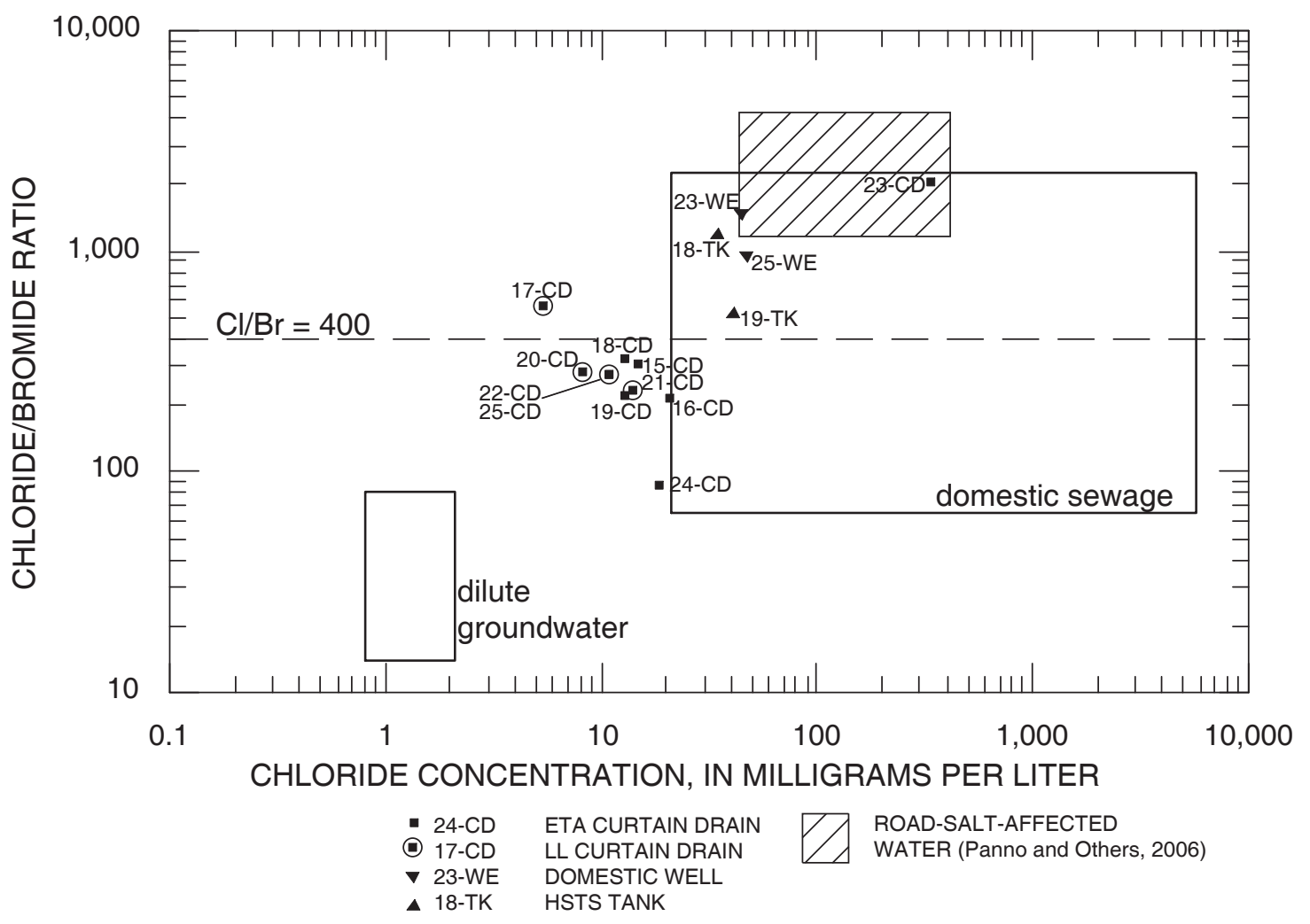

Figure 6. Relation of chloride concentration to chloride-bromide ratios for water from home sewage-treatment systems (HSTSs), HSTS curtain drains, and domestic-supply wells, Medina County, Ohio.

not used in this analysis because the $\mathrm{Cl} / \mathrm{Br}$ ratios indicate that the wells may be affected by halite dissolution (fig. 6). The possible impact of halite dissolution is also supported from work by Eberts and others (1990), who used bromide-tochloride ratios to compare ground water and brine in nearby Geauga County (fig. 1); the ratios in the samples from the two wells in Medina County are within the ranges identified as a mixture of ground water and local halite-solution brines (fig. 25 in Eberts and others, 1990). Therefore, other data were used to define the "dilute ground-water" box on figure 6; the box was based on samples from 7 of 12 wells completed in glacial deposits in Geauga County; data from the other wells were not used because of indications of ground water mixing with halite solution and/or anthropogenic affects (Eberts and others, 1990; Jagucki and Darner, 2001).

The data points for 10 of the curtain drains in this study fall between the boxes for dilute ground water and domestic sewage (fig. 6), possibly indicating a mixing of these waters in the drains. The data point for the 11th site, MD-23, plots within both the sewage and the road-salt boxes. The sample from the drain at MD-23 has an unusually high concentration of chloride that may reflect the use of a water softener at the site and/or its proximity to the road and road salt. Chloride concentrations were much lower at sites MD-21 and MD-22 where softeners also were in use, but these sites are farther from the road (table 1). This may indicate that road-salt effects have a greater impact at site MD-23 than the use of a water softener.

For the majority of the sites, the $\mathrm{Cl} / \mathrm{Br}$ ratios in samples from the drains are less than 1,000 , which is generally the lower end of the range of ratios reported for road-salt-affected waters. The $\mathrm{Cl} / \mathrm{Br}$ ratios in the samples from the 10 drains plotting between the dilute ground water and sewage boxes in figure 6 range from 86 to 550. Jagucki and Darner (2001) note that the theoretical upper limit of the $\mathrm{Cl} / \mathrm{Br}$ ratio for natural water is 400 ; they considered ratios in the $110-400$ range as indicating possible effects of anthropogenic sources and that those in the 400-10,000 range as indicating probable effects of anthropogenic sources. Using the ranges from Jagucki and Darner (2001), the $\mathrm{Cl} / \mathrm{Br}$ ratios from samples from the curtain 
drains (table 3, fig. 6) at sites MD-15, MD-16, MD-18, MD19, MD-20, MD-21, MD-22 and MD-25, indicate possible anthropogenic sources, whereas the samples from sites MD-17 and MD-23 indicate probable anthropogenic sources. $\mathrm{Cl} / \mathrm{Br}$ ratios indicating possible or probable anthropogenic sources in curtain-drain samples were virtually the same for both ETA and LL systems. There was no meaningful difference between ETA and LL systems with respect to $\mathrm{Cl} / \mathrm{Br}$ ratios.

\section{Coliphage}

Somatic coliphage was detected in seven HSTSs, but F-specific coliphage was detected in only two HSTSs, MD-16 and MD-22 (table 4). Somatic coliphage was detected in one of the two curtain-drain samples tested. No F-specific coliphage was detected in either of the two curtain-drain samples tested.

Table 4. Results of analyses of bacteria and coliphage in samples from wells and home sewage-treatment system sites in Medina County, Ohio.

[CD, curtain drain; HSTS, home sewage-treatment system; WE, residential water well; col/100 mL, colonies per 100 milliliters; plaq/100 mL, plaques per 100 milliliters; <, less than; --, no data; E, estimated]

\begin{tabular}{|c|c|c|c|c|c|}
\hline Site name & Sample source & Date & $\begin{array}{c}\text { E. coli } \\
(\text { col/100 mL) }\end{array}$ & $\begin{array}{c}\text { Somatic } \\
\text { coliphage } \\
\text { (plaq/100 mL) }\end{array}$ & $\begin{array}{c}\text { F-specific } \\
\text { coliphage } \\
\text { (plaq/100 mL) }\end{array}$ \\
\hline \multicolumn{6}{|c|}{ Evaporation-transpiration-absorption systems (ETA) } \\
\hline \multirow[t]{2}{*}{ MD-15 } & $\mathrm{CD}$ & $6-21-2004$ & 110 & -- & -- \\
\hline & HSTS & & 160,000 & $<1$ & $<1$ \\
\hline \multirow[t]{2}{*}{ MD-16 } & $\mathrm{CD}$ & $6-21-2004$ & 300 & -- & $<1$ \\
\hline & HSTS & & 96,000 & $<1$ & 69,000 \\
\hline \multirow[t]{2}{*}{ MD-18 } & $\mathrm{CD}$ & $6-22-2004$ & 760 & -- & -- \\
\hline & HSTS & & 830 & 1,600 & $<1$ \\
\hline \multirow[t]{2}{*}{ MD-19 } & $\mathrm{CD}$ & $6-22-2004$ & 47 & -- & -- \\
\hline & HSTS & & 12,000 & $<1$ & $<1$ \\
\hline \multirow[t]{3}{*}{ MD-23 } & $\mathrm{CD}$ & $6-23-2004$ & 61 & -- & -- \\
\hline & HSTS & & 16,000 & 67 & $<1$ \\
\hline & WE & & $<1$ & -- & -- \\
\hline \multirow[t]{2}{*}{ MD-24 } & $\mathrm{CD}$ & $6-24-2004$ & 22 & 6,000 & -- \\
\hline & HSTS & & 250 & 27 & $<1$ \\
\hline \multicolumn{6}{|c|}{ Leach-line systems (LL) } \\
\hline \multirow[t]{2}{*}{ MD-17 } & $\mathrm{CD}$ & $6-21-2004$ & 14 & -- & -- \\
\hline & HSTS & & 29,000 & $<1$ & $<1$ \\
\hline \multirow[t]{2}{*}{ MD-20 } & $\mathrm{CD}$ & $6-22-2004$ & 30 & -- & -- \\
\hline & HSTS & & 350 & 70 & $<1$ \\
\hline \multirow[t]{2}{*}{ MD-21 } & $\mathrm{CD}$ & $6-22-2004$ & 230 & -- & -- \\
\hline & HSTS & & 620 & 17 & $<1$ \\
\hline \multirow[t]{2}{*}{ MD-22 } & $\mathrm{CD}$ & $6-23-2004$ & 60 & $<1$ & $<1$ \\
\hline & HSTS & & 720 & 200 & 28 \\
\hline \multirow[t]{3}{*}{ MD-25 } & $\mathrm{CD}$ & $6-24-2004$ & E 1 & -- & -- \\
\hline & HSTS & & 11,000 & 453 & $<1$ \\
\hline & WE & & $<1$ & -- & -- \\
\hline
\end{tabular}


On the basis of findings in a USGS study in Oregon in which F-specific coliphage was detected in 19 out of 51 samples (S.R. Hinkle, U.S. Geological Survey, oral commun., 2004), it was expected that sufficient coliphage would be detected in this study for genotyping analysis. However, only 2 of the 11 sites had detectable levels of F-specific coliphage in the HSTS, and none was detected in the curtain drains at these sites; therefore, no genotyping analyses were possible.

\section{E. coli Bacteria}

Concentrations of $E$. coli in the HSTSs ranged from 250 to $160,000 \mathrm{col} / 100 \mathrm{~mL}$, with a median of $11,000 \mathrm{col} / 100 \mathrm{~mL}$ (table 4). Concentrations of E. coli in the curtain drains ranged from 1 to $760 \mathrm{col} / 100 \mathrm{~mL}$, with a median of $60 \mathrm{col} / 100 \mathrm{~mL}$. At all sites, the concentrations of $E$. coli in the curtain drains were less than those in the HSTS. With respect to median concentrations, there was an order of magnitude reduction between the HSTS and curtain drains at LL systems (720 to 30 $\mathrm{col} / 100 \mathrm{~mL}$ ) and three orders of magnitude reduction at ETA systems $(14,000$ to $80 \mathrm{col} / 100 \mathrm{~mL})$. No E. coli were detected in the well-water samples.

Of the 11 samples from curtain drains, only 2 had concentrations of $E$. coli exceeding the single-sample bathing-water standard of $235 \mathrm{col} / 100 \mathrm{~mL}$ (Ohio Environmental Protection Agency, 2003b). Only one site had a concentration exceeding the more relevant standard of $576 \mathrm{col} / 100 \mathrm{~mL}$ for secondary contact such as wading, which could occur if, for example, children were to play at or near the curtain-drain outfalls (fig. 5).

Concentrations of $E$. coli in the drains from the six ETA systems ranged from an estimated 22 to $760 \mathrm{col} / 100 \mathrm{~mL}$, with a median concentration of $86 \mathrm{col} / 100 \mathrm{~mL}$. Concentrations in the drains from the five LL systems ranged from an estimated 1 to $230 \mathrm{col} / 100 \mathrm{~mL}$, with a median concentration of 30 $\mathrm{col} / 100 \mathrm{~mL}$. Although it appears that the E. coli concentrations at LL systems were generally lower than at ETA systems, the small number of samples makes it impossible to evaluate relative concentrations with certainty. For example, if the curtaindrain sample from MD-18 (highest $E$. coli concentration) had not been collected, the range and median of the remaining five ETA curtain-drain samples would have been 22 to $300 \mathrm{col} / 100$ $\mathrm{mL}$ and $61 \mathrm{col} / 100 \mathrm{~mL}$ - comparable to the LL systems.

Although there is no reason to discount the MD-18 sample, the differences between the two systems would have to be considerable to be significant given so few samples.

Presumptive $E$. coli from the sites were isolated from the agar plates, saved by freezing, and later characterized by rep-PCR analysis. The rep-PCR process produces a graphical display of the genetic makeup of an isolate, similar to a barcode. The similarity of any two isolates can be determined by comparing their genetic patterns. (See Dumouchelle and Stoeckel, 2005, for more detail.) A representation of 14 rep-PCR patterns is shown on figure 7. Each banding pattern represents a portion of the genetic makeup of one isolate.
On figure 7, differences in isolates A and B cannot be distinguished within the precision of the method; the same is true for isolates $\mathrm{C}$ through $\mathrm{E}$. Therefore, isolates $\mathrm{A}$ and $\mathrm{B}$ are considered the same, as are isolates $\mathrm{C}$ through E. Similar isolates are assigned to a sequentially numbered group called an OTU (operational taxonomic unit). In some cases, professional judgment is required to decide whether isolates belong to an OTU. For example, isolates A-B and C-E (fig. 7) appear to be different on the basis of the intensity of a single band, and are thus considered genetically distinct and assigned to separate OTUs. It is more clear, however, that isolate $\mathrm{F}$ is different from isolates A-E.

On the basis of rep-PCR results, 97 OTUs were identified in this study. Many OTUs contained isolates from only a single sample source, such as an HSTS. Nineteen OTUs contained isolates from more than one sample source (table 5). In a previous study, detection of the same OTU in the HSTS and adjacent curtain drain was considered evidence of transport of partially treated wastewater from the HSTS to the drain (Dumouchelle and Stoeckel, 2005). In that previous study, no OTUs were detected at multiple sites; however, in this study, 10 OTUs contained isolates from two unrelated sites and 3 OTUs (14, 27, and 55) contained isolates from three unrelated sites (table 5). Five OTUs from three sites had shared isolates from the curtain-drain and tank samples at a single site-OTU 1 at MD-23, OTU 37 at MD-16, and OTUs 21, 76, and 80 at MD-24 (table 5) - but these three sites also shared isolates with unrelated sites. Although the detection of a given OTU in an HSTS and curtain drain remains evidence of wastewater migration, the multiple occurrences of the same OTU at unrelated HSTSs indicates that the method cannot be considered positive proof of origin from a single household.

\section{Utility of Study Approaches and Inferences From Available Data}

One of the objectives of this study was to evaluate several indicators to test for the presence of HSTS-derived water in curtain drains. Two water-quality indicators were used-nutrient, concentrations and $\mathrm{Cl} / \mathrm{Br}$ ratios - and three microbiological indicators were used-E. coli concentrations, coliphage genotyping, and genetic fingerprinting of E. coli.

The results of the tests of various indicators evaluated in this study are summarized in table 6 . Of these, only the $\mathrm{Cl} / \mathrm{Br}$ ratios provided evidence of the presence of HSTS-derived water in curtain drains. The nutrient data were not particularly useful because no orthophosphate was detected in any curtain drains, and only one site had a nitrate concentration that could indicate partially treated HSTS water in the curtain drain. The nitrate concentration in water from the curtain drain at MD-15, however, was $3.5 \mathrm{mg} / \mathrm{L}$, at the low end of the range of 3 to $10 \mathrm{mg} / \mathrm{L}$ that indicates possible anthropogenic effects. $\mathrm{The} \mathrm{Cl} / \mathrm{Br}$ ratios were useful in indicating the movement of HSTS-derived water to the drains. When a mixing plot (fig. 6) 


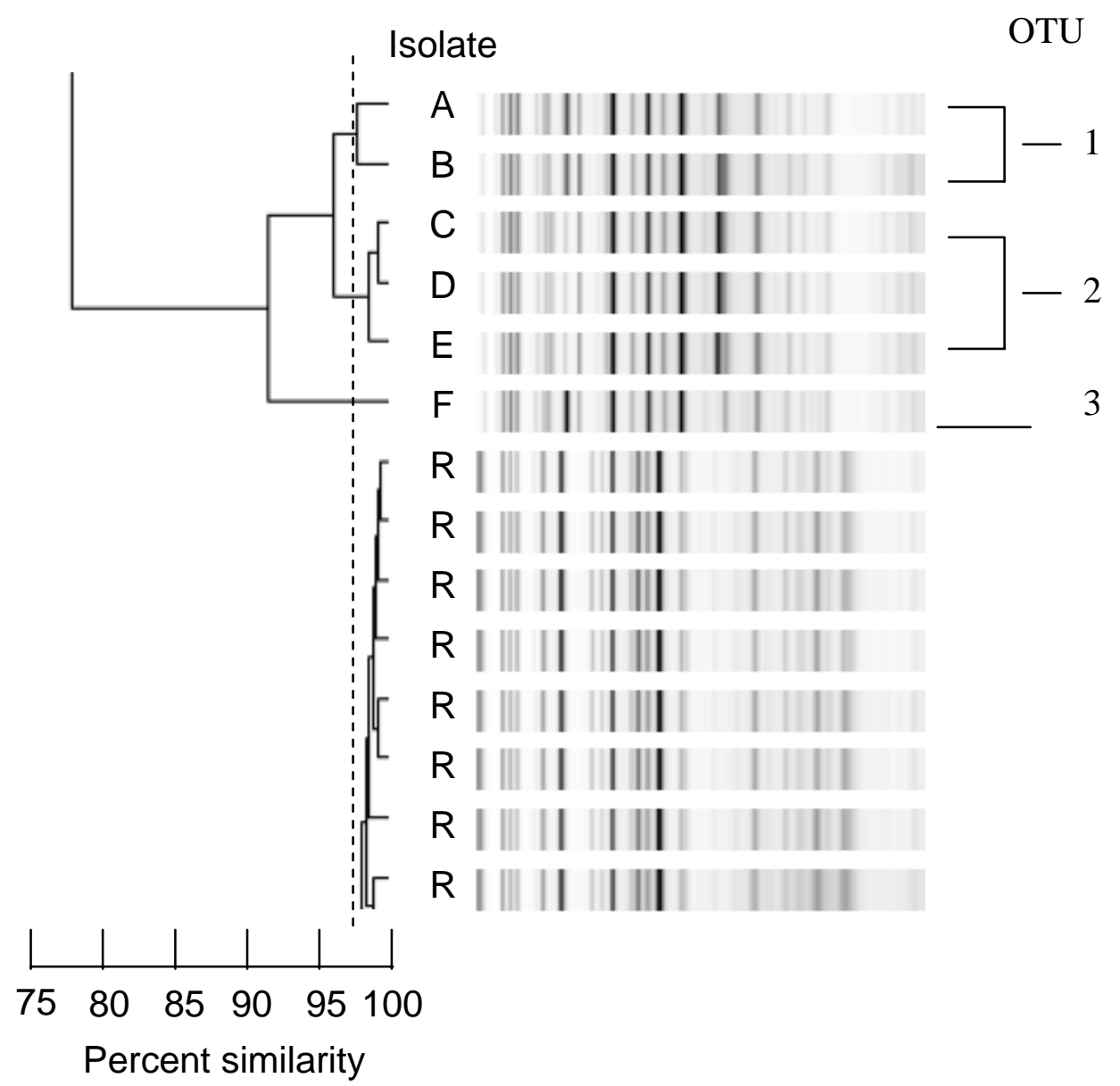

The bars labeled A-F are individual isolates. The banding patterns on the bars represent a portion of genetic information for the isolate. The bars labeled $\mathrm{R}$ are repeated measurements of a control strain (E. coli ATCC 25922). The percent similarity of these control measurements is indicated by the lines to the left of the bars - the controls are greater than 97 percent similar. The dashed line indicates the precision of the analytical method as determined by the repeated measurements $(\mathrm{R})$.

The measurement precision (dashed line) and professional judgment are used to assign the isolates A-F to an arbitrary operational taxonomic unit (OTU). Based on the similarity of the banding patterns, isolates $\mathrm{A}$ and $\mathrm{B}$ are assigned to OTU 1, isolates $\mathrm{C}$, D and $\mathrm{E}$ are assigned to OTU 2, and isolate $\mathrm{F}$ is assigned to OTU 3.

Figure 7. Example of results of rep-PCR analysis showing six isolates and multiple measurements of a single isolate, demonstrating the reproducibility of results. 
Table 5. Sites and numbers of isolates in those operational taxonomic units (OTU) found from more than one source from samples in Medina County, Ohio.

[ OTU, operational taxonomic unit; HSTS, home sewage-treatment system]

\begin{tabular}{|c|c|c|c|c|c|}
\hline OTU & Sample source & $\begin{array}{c}\text { Number of } \\
\text { isolates }\end{array}$ & OTU & Sample source & $\begin{array}{c}\text { Number of } \\
\text { isolates }\end{array}$ \\
\hline 1 & $\begin{array}{l}\text { MD-23 curtain drain } \\
\text { MD- } 23 \text { HSTS }\end{array}$ & $\begin{array}{l}6 \\
8\end{array}$ & 30 & $\begin{array}{l}\text { MD-16 curtain drain } \\
\text { MD-17 HSTS }\end{array}$ & $\begin{array}{l}2 \\
1\end{array}$ \\
\hline 7 & $\begin{array}{l}\text { MD-20 curtain drain } \\
\text { MD- } 24 \text { HSTS }\end{array}$ & $\begin{array}{l}1 \\
1\end{array}$ & 32 & $\begin{array}{l}\text { MD-18 dog scat } \\
\text { MD-18 HSTS }\end{array}$ & $\begin{array}{l}4 \\
1\end{array}$ \\
\hline 11 & $\begin{array}{l}\text { MD-23 curtain drain } \\
\text { MD-24 curtain drain }\end{array}$ & $\begin{array}{l}1 \\
2\end{array}$ & 34 & $\begin{array}{l}\text { MD-18 HSTS } \\
\text { MD-24 curtain drain }\end{array}$ & $\begin{array}{l}1 \\
1\end{array}$ \\
\hline 12 & $\begin{array}{l}\text { MD-16 curtain drain } \\
\text { MD-18 curtain drain }\end{array}$ & $\begin{array}{l}1 \\
1\end{array}$ & 37 & $\begin{array}{l}\text { MD-16 curtain drain } \\
\text { MD- } 16 \text { HSTS }\end{array}$ & $\begin{array}{l}2 \\
2\end{array}$ \\
\hline 14 & $\begin{array}{l}\text { MD-18 surface scat (dog) } \\
\text { MD-21 curtain drain } \\
\text { MD-24 curtain drain }\end{array}$ & $\begin{array}{l}1 \\
1 \\
3\end{array}$ & 50 & $\begin{array}{l}\text { MD-20 curtain drain } \\
\text { MD-21 curtain drain }\end{array}$ & $\begin{array}{l}1 \\
3\end{array}$ \\
\hline 21 & $\begin{array}{l}\text { MD-24 curtain drain } \\
\text { MD-24 HSTS }\end{array}$ & $\begin{array}{l}1 \\
4\end{array}$ & 55 & $\begin{array}{l}\text { MD-19 curtain drain } \\
\text { MD-20 curtain drain } \\
\text { MD-21 curtain drain }\end{array}$ & $\begin{array}{l}1 \\
3 \\
1\end{array}$ \\
\hline 22 & $\begin{array}{l}\text { MD-16 curtain drain } \\
\text { MD-19 HSTS }\end{array}$ & $\begin{array}{l}1 \\
7\end{array}$ & 75 & $\begin{array}{l}\text { MD-17 curtain drain } \\
\text { MD-24 curtain drain }\end{array}$ & $\begin{array}{l}1 \\
1\end{array}$ \\
\hline 24 & $\begin{array}{l}\text { MD-16 HSTS } \\
\text { MD-24 curtain drain }\end{array}$ & $\begin{array}{l}1 \\
1\end{array}$ & 76 & $\begin{array}{l}\text { MD-24 curtain drain } \\
\text { MD-24 HSTS }\end{array}$ & $\begin{array}{l}2 \\
2\end{array}$ \\
\hline 25 & $\begin{array}{l}\text { MD-19 curtain drain } \\
\text { MD-22 HSTS }\end{array}$ & $\begin{array}{l}2 \\
9\end{array}$ & 80 & $\begin{array}{l}\text { MD-24 curtain drain } \\
\text { MD-24 HSTS }\end{array}$ & $\begin{array}{l}2 \\
1\end{array}$ \\
\hline 27 & $\begin{array}{l}\text { MD-15 curtain drain } \\
\text { MD-17 curtain drain } \\
\text { MD-24 curtain drain }\end{array}$ & $\begin{array}{l}2 \\
3 \\
2\end{array}$ & & & \\
\hline
\end{tabular}

was generated from the ratios and chloride concentrations, the curtain-drain samples from 10 of the 11 sites reflected some mixing of dilute ground water and HSTS-derived water; data for the 11th site plotted within the range of sewage- and roadsalt-affected water.

In a previous study, coliphage was detected in 37 percent of samples; thus, it was hoped that a similar detection frequency would provide sufficient opportunity to detect coliphage in a curtain drain. Coliphage was detected only in two HSTSs (18 percent of samples), however, decreasing the chance of detecting it in a drain. Thus, the F-specific coliphage genotyping was not considered useful for indicating HSTS-derived waster in curtain drains. Although E. coli were detected in 10 of the 11 curtain drains, detection alone cannot identify the source of the bacteria. Previous studies had indicated that genetic analysis methods such as rep-PCR might be useful for linking the source of $E$. coli in a curtain drain sample to the HSTS; however, the multiple links between unrelated sites seen in this study shows that this approach cannot provide definitive answers in this setting.

Previous studies had indicated that each of the approaches used in this study could be useful in determining in the presence of HSTS-derived water in curtain drains; however, this study encountered difficulties in applying most of these approaches. Hence, caution is necessary when using any of these methods individually. Although the use of $\mathrm{Cl} / \mathrm{Br}$ ratios appears promising, the use of multiple approaches to provide several lines of evidence in determining the effects of HSTS on curtain-drain water quality is warranted. Additional studies investigating other water-quality based indicators of HSTSaffected water, such as the presence of wastewater compounds, surfactants, or optical brighteners, and/or other microbiological constituents, may be useful as well.

Another objective of this study was to describe the results of the various approaches with respect to ETA and LL systems. The small sample size of this reconnaissance assessment 
Table 6. Summary of the utility of indicators used in this study for indicating the movement of partially untreated wastewater from home sewage-treatment systems to associated curtain drain.

[>, greater than; mg/L, milligrams per liter; HSTS, home sewage-treatment systems; rep-PCR, repetitive DNA element polymerase chain reaction; $x$, indicates evidence of untreated wastewater movement; --, no evidence of untreated wastewater movement]

\begin{tabular}{|c|c|c|c|c|c|c|}
\hline \multirow{2}{*}{$\begin{array}{c}\text { Site } \\
\text { number }\end{array}$} & \multirow{2}{*}{$\begin{array}{c}\text { Nitrate concentra- } \\
\text { tion a } \\
>3 \mathrm{mg} / \mathrm{L}\end{array}$} & \multicolumn{3}{|c|}{ Chloride / bromide ratio a } & \multirow{2}{*}{$\begin{array}{c}\text { E. coli } \\
\text { detected } \\
\text { in curtain } \\
\text { drain }^{\mathrm{d}}\end{array}$} & \multirow{2}{*}{$\begin{array}{c}\text { Indication of a link } \\
\text { between the HSTS and } \\
\text { curtain drain } \\
\text { by way of rep-PCR }\end{array}$} \\
\hline & & $\begin{array}{c}x-y \\
\text { plot }^{b}\end{array}$ & $110-400^{c}$ & $>400 \mathrm{c}$ & & \\
\hline \multicolumn{7}{|c|}{ Evaporation-transpiration-absorption systems (ETA) } \\
\hline MD-15 & $\mathrm{x}$ & $\mathrm{x}$ & $\mathrm{x}$ & -- & $\mathrm{x}$ & -- \\
\hline MD-16 & -- & $\mathrm{x}$ & $\mathrm{x}$ & -- & $\mathrm{x}$ & $\mathrm{x}$ \\
\hline MD-18 & -- & $\mathrm{x}$ & $\mathrm{x}$ & -- & $\mathrm{x}$ & -- \\
\hline MD-19 & -- & $\mathrm{x}$ & $\mathrm{x}$ & -- & $\mathrm{x}$ & -- \\
\hline MD-23 & -- & $\mathrm{x}$ & -- & $\mathrm{x}$ & $\mathrm{x}$ & $\mathrm{x}$ \\
\hline MD-24 & -- & & -- & -- & $\mathrm{x}$ & $x^{e}$ \\
\hline \multicolumn{7}{|c|}{ Leach-line systems (LL) } \\
\hline MD-17 & -- & $\mathrm{x}$ & -- & $\mathrm{x}$ & $\mathrm{x}$ & -- \\
\hline MD-20 & -- & $\mathrm{x}$ & $\mathrm{x}$ & -- & $\mathrm{x}$ & -- \\
\hline MD-21 & -- & $\mathrm{x}$ & $\mathrm{x}$ & -- & $\mathrm{x}$ & -- \\
\hline MD-22 & -- & $\mathrm{x}$ & $\mathrm{x}$ & -- & $\mathrm{x}$ & -- \\
\hline MD-25 & -- & $\mathrm{x}$ & $\mathrm{x}$ & -- & $--^{f}$ & -- \\
\hline
\end{tabular}

${ }^{\text {aS }}$ See text for explanation of why the $\mathrm{Cl} / \mathrm{Br}$ ratio and these concentrations are used as indicators.

${ }^{\mathrm{b}}$ Based on chloride/bromide plot in figure 6 .

${ }^{\mathrm{c}}$ Range of 110-400 indicates possible anthropogenic effects; values of ratio greater than 400 indicates probable effects.

${ }^{\mathrm{d}}$ The presence of $E$. coli indicates fecal contamination but does not indicate the source of contamination.

${ }^{\mathrm{e}}$ Indication of a link between the curtain drain and HSTS by more than one operational taxonomic unit (OTU).

${ }^{\mathrm{f}}$ Estimated concentration of 1 colony per 100 milliliters.

precludes rigorous statistical comparisons; therefore, only simple comparisons between the two systems could be made. Although the nitrate concentrations in curtain-drain samples from the ETA systems had a slightly larger range and median value than did samples from the LL systems, the values for both systems were, with one exception, below the range that can be considered indicative of possible anthropogenic effects; therefore, the differences were not particularly meaningful. There were no differences between the two systems with respect to the chloride-bromide ratios, nor were there differences with respect to chloride concentrations. The curtaindrain samples from the ETA systems had somewhat higher bromide concentrations, but the reason for this was unclear. E. coli bacteria were found in the curtain-drain samples from both systems, with ETA systems having higher concentrations, though the difference between both systems is not statistically significant. Although only ETA sites showed a link between the HSTS and curtain-drain samples on the basis of the rep-PCR analysis, the numerous links between unrelated sites in this study means that such links were ambiguous. Therefore, although the curtain-drain samples from the ETA systems appear to show slightly more evidence of the presence of HSTS-derived water than do samples from the LL systems (table 6), the best evidence is from the $\mathrm{Cl} / \mathrm{Br}$ ratios, and both ETA and LL systems reflect the presence of HSTS-derived water. Therefore, with the data from this reconnaissance study, it is not possible to state definitively whether there are any differences between the ETA and LL systems with respect to the water quality in curtain drains.

\section{Summary and Conclusions}

A variety of home sewage-treatment system (HSTS) designs are used in Ohio. Many of these systems use curtain or perimeter drains to depress the level of the subsurface water in and around the HSTS. There are concerns that these drains could release untreated wastewater and potential pathogens to 
ground-water and surface-water bodies. The quality of water from two different HSTS designs in Medina County, Ohio, was investigated in this reconnaissance study, in cooperation with the Medina County Health Department. Several approaches were evaluated in this study for testing for the presence of HSTS-derived water in the curtain drains. Water samples were collected at 11 sites from curtain drains, septic tanks and residential water wells (at 2 of the 11 sites) and analyzed for nutrients, chloride, bromide, coliphage, and E. coli bacteria. In addition, genetic fingerprinting (rep-PCR) was used to determine whether bacteria in the curtain drains could be linked to the HSTS. Six evaporation-transpiration-absorption (ETA) and five leach-line (LL) systems were investigated.

Nitrate concentrations in the curtain drains ranged from an estimated 0.03 to $3.53 \mathrm{mg} / \mathrm{L}$. Concentrations of chloride in 10 of the 11 curtain drains ranged from 5.5 to $21 \mathrm{mg} / \mathrm{L}$; the chloride concentration in the 11th curtain drain was $340 \mathrm{mg} / \mathrm{L}$. Bromide concentrations in the curtain drains ranged from an estimated 0.01 to $0.22 \mathrm{mg} / \mathrm{L}$. Chloride-bromide $(\mathrm{Cl} / \mathrm{Br})$ ratios ranged from 86 to 2,000. No F-specific coliphage was found in any curtain-drain samples. Concentrations of $E$. coli in all of the curtain drains ranged from an estimated 1 to $760 \mathrm{col} / 100$ $\mathrm{mL}$; the Ohio secondary-contact water-quality standard of 576 $\mathrm{col} / 100 \mathrm{~mL}$ was exceeded in only one sample.

Nutrient concentrations, $\mathrm{Cl} / \mathrm{Br}$ ratios, genotyping of coliphage, E. coli concentrations, and genetic fingerprinting of bacteria were evaluated for their usefulness in determining whether partially treated wastewater was present in the curtain drains. Nutrient concentrations were too low to be useful indicators. The chloride-bromide ratios were useful and reflected a mixture of ground water and HSTS-derived water in 10 of the 11 the sampled drains; the water in the 11th drain may be affected by road-salt contamination. Coliphage was not detected in the curtain drains, so genotyping could not be attempted.

Although it appeared from multiple lines of evidence that the curtain-drain samples from the ETA systems showed slightly more evidence of the presence of HSTS water than did the LL systems, the most promising evidence is from the $\mathrm{Cl} / \mathrm{Br}$ ratios, which indicate that both ETA and LL systems were affected by the presence of HSTS-derived water. Therefore, with the data from this reconnaissance study, it is not possible to state definitively whether there are any differences between the ETA and LL systems with respect to the water quality in curtain drains.

\section{Acknowledgments}

The author thanks the numerous property owners who allowed access to their HSTS and yards.

\section{References Cited}

ASTM International, 2002, Standard practice for installation of thermoplastic pipe and corrugated pipe in septic tank leach fields: West Conshohocken, Pa., ASTM F481-97 (2002).

Bacterial Barcodes, 2004, DiversiLab protocols and application profiles, accessed December 8, 2004, at http://www.bacbarcodes.com/dl_application_profile.htm

Baker, B.B, Wallrabenstein, L,K., Richards, R.P., and Creamer, N.L, 1989, Nitrate and pesticides in private wells of Ohio, a state atlas: Tiffin, Ohio, Heidelberg College, Water Quality Laboratory, part 1, 71 p.

Beekwilder, J., Nieuwenhuizen, R., Havelaar, A.H., and van Duin, J., 1996, An oligonucleotide hybridization assay for the identification and enumeration of F-specific RNA phages in surface water: Journal of Applied Bacteriology, v. 80 , p. $1791-86$.

Behl, E., Davis, S.N., and Goldowitz, J., 1987, Cl/Br ratios as an environmental tracer of anthropogenically altered waters: Geological Society of America Abstracts with Programs, v. 19 , p. 585 .

Carson, C.A., Shear, B.L., Ellersieck, M.R., and Schnell, J.D., 2003, Comparison of ribotyping and repetitive extragenic palindromic-PCR for identification of fecal Escherichia coli from humans and animals: Applied and Environmental Microbiology, v. 69, no. 3, p. 1836-1839.

Caugant, D.A., Levin, B.R., and Selander, R.K., 1981, Genetic diversity and temporal variation in the $E$. coli population of a human host: Genetics, v. 98, p. 467-490.

Davis, S.N, Whittemore, D.O., and Fabryka-Martin, June, 1998, Uses of chloride/bromide ratios in studies of potable water: Ground Water, v. 36 , no. 2, p. 338-350.

Dombek, P.E., Johnson, L.K., Zimmerley, S.T., and Sadowsky, M.J., 2000, Use of repetitive DNA sequences and the PCR to differentiate Escherichia coli isolates from human and animal sources: Applied and Environmental Microbiology, v. 66 , no. 6, p. 2572-2577.

Drever, J.I., 1988, The geochemistry of natural waters ( $2 \mathrm{~d}$ ed.): Englewood Cliffs, N.J., Prentice Hall, p. 329.

Dumouchelle, D.H., and Stoeckel, D.M., 2005, Preliminary investigation of wastewater-related contaminants near home sewage treatment systems in Ohio: U.S. Geological Survey Open-File Report 2005-1282, 31 p.

Eberts, S.M., Bair, E.S., and de Roche, J.T., 1990, Geohydrology, ground-water quality, and simulated ground-water flow, Geauga County, Ohio: U.S. Geological Survey WaterResources Investigations Report 90-4026, 117 p. 
Fishman, M.J., ed., 1993, Methods of analysis by the U.S. Geological Survey National Water Quality LaboratoryDetermination of inorganic and organic constituents in water and fluvial sediments: U.S. Geological Survey OpenFile Report 93-125, 217 p.

Fishman, M.J., and Friedman, L.C., eds., 1989, Methods for determination of inorganic substances in water and fluvial sediments: U.S. Geological Survey Techniques of WaterResources Investigations, book 5, chap. A1, 545 p.

Francy, D.S., Bushon, R.N, Luzano, E.J, Brady, A.M.G., Kephart, C.M, and Stoeckel, D.M., 2004, Quality assurance/ quality control manual, Ohio Water Microbiology Laboratory, accessed December 9, 2004, at http://oh.water.usgs.gov/micro/qcmanual/manual.html

Freeze R.A., and Cherry, J.A., 1979, Groundwater: Englewood Cliffs, N.J., Prentice-Hall, 604 p.

Hayhurst, E.N., Milliron, E.L., and Steiger, J.R., 1977, Soil survey of Medina County: U.S. Department of Agriculture, Soil Conservation Service, 119 p., 53 sheets, scale 1:15,840.

Hem, J.D., 1989, Study and interpretation of the chemical characteristics of natural waters ( $3 \mathrm{~d}$ ed.): U.S. Geological Survey Water-Supply Paper 2254, 263 p.

Hsu, F.-C., Shieh, Y.-S., van Duin, J., Beekwilder, M.J., and Sobsey, M.D., 1995, Genotyping male-specific RNA coliphages by hybridization with oligonucleotide probes: Applied and Environmental Microbiology, v. 61, no. 11, p. 3960-3966.

Jagucki, M.L., and Darner, R.A., 2001, Ground-water quality in Geauga County, Ohio-Review of previous studies, status in 1999, and comparision of 1986 and 1999 data: U.S. Geological Survey Water-Resources Investigations Report 01-4160, 60 p.

Johnson, L.K., Brown, M.B., Carruthers, E.A., Ferguson, J.A., Dombek, P.E., and Sadowsky, M.J., 2004, Sample size, library composition, and genotypic diversity among natural populations of Escherichia coli from different animals influence accuracy of determining sources of fecal pollution: Applied and Environmental Microbiology, v. 70, no. 8, p. $4478-4485$.

Jones, A.L., and Sroka, B.N., 1997, Effects of highway deicing chemicals on shallow unconsolidated aquifers in Ohio- Interim report, 1988-1993: U.S. Geological Survey Water-Resources Investigations Report 97-4027, 139 p.

Kariuki, S., Gilks, C., Kimari, J., Obanda, A., Muyodi, J., Waiyaki, P., and Hart, C.A., 1999, Genotype analysis of Escherichia coli strains isolated from children and chickens living in close contact: Applied and Environmental Microbiology, v. 65, no. 2, p. 472-476.
Mancl, Karen, and Slater, David, 2001, Suitability assessment of Ohio's soils for soil-based wastewater treatment: Ohio Journal of Science, v. 101, no. 3/4, p. 48-56.

McLellan, S.L., 2004, Genetic diversity of Escherichia coli isolated from urban rivers and beach water: Applied and Environmental Microbiology, v. 70, no. 8, p. 4658-4665.

Noble, R.T., Allen, S.M., Blackwood, A.D., Chu, W., Jiang, S.C., Lovelace, G.L., Sobsey, M.D., Stewart, J.R., and Wait, D.A., 2003, Use of viral pathogens and indicators to differentiate between human and non-human fecal contamination in a microbial source tracking comparison study: Journal of Water and Health, v. 1, no. 4, p. 195-207.

Ohio Environmental Protection Agency, 2003a, Biological and water quality study of the Big Walnut Creek Basin, 2000: Technical report DSW/EAS 2003-11-10, accessed June 2005 at http://www.epa.state.oh.us/dsw/documents/ BigWalnutCreekTSD.pdf

Ohio Environmental Protection Agency, 2003b, Water use definitions and statewide criteria: Ohio Administrative code, chap. 3745-1-07, July 1, 2003, 31 p.

Ohio Department of Development, 2005, Annual estimates of the population for Ohio counties, April 1, 2000, to July 1, 2004, accessed September 2005 at http://www.odod.state. oh.us/research/files/p100000004.pdf

Panno S.V., Hackley, K.C., Hwang, H.H., Greenberg, S., Krapac, I.G., Landsberger, S., and O’Kelly, D.J., 2002, Source identification of sodium and chloride contamination in natural waters-Preliminary results, in Illinois Groundwater Consortium annual conference, 12th, April 20, 2002, Proceedings: Accessed Feburary 2004 at http//:www.siu. edu/orda/igc/proceedings/02/panno.pdf

Panno, S.V., Hackley, K.C., Hwang, H.H., Greenberg, S.E., Krapac, I.G., Landsberger, S., and O’ Kelly, D.J., 2006, Characterization and identification of $\mathrm{Na}-\mathrm{Cl}$ sources in ground water: Ground Water, v. 44, no. 2, p. 176-187.

Rademaker, J.L.W, and de Bruijn, F.J., 1997, Charcterization and classification of microbes by REP-PCR genomic fingerprinting and computer assisted pattern analysis, in Caetano-Anolles, G., and Gresshoff, P.M., eds., DNA markers-Protocols, applications, and overviews: New York, Wiley-Liss, p. 151-172.

Stoeckel, D.M., 2005, Application of microbial source tracking tools for water-quality investigations: U.S. Geological Survey Techniques and Methods, book 2, chap. 3A, 49 p.

Thomas, M.A, 2000, The effect of residential development on ground-water quality near Detroit, Michigan: Journal of the American Water Resources Association, v. 36, no. 5, p. 1023-1038. 
U.S. Environmental Protection Agency, 2000, Improved enumeration methods for the recreational water quality indicators-Enterococci and Escherichia coli: Washington D.C., Office of Science and Technology, $27 \mathrm{p}$.

U.S. Environmental Protection Agency, 2001, Method 1602Male-specific $(\mathrm{F}+)$ and somatic coliphage in water by single agar layer (SAL) procedure, accessed December 9, 2004, at http://www.epa.gov/nerlcwww/1602ap01.pdf

U.S. Environmental Protection Agency, 2004, List of drinking water contaminants \& MCLs, accessed October 20, 2004, at http://www.epa.gov/safewater/mcl.html

Vengosh, Avner, and Pankratov, Irena, 1998, Chloride/bromide and chloride/fluoride ratios of domestic sewage effluents and associated contaminated ground water: Ground Water, v. 36 , no. 5 , p. 815-824.

Whittam, T.S., 1989, Clonal dynamics of Escherichia coli in its natural habitat: Antonie van Leeuwenhoek, v. 55, p. 23-32.

Whittmore, D.O., 1998, Bromide as a tracer in groundwater studies-Geochemistry and analytical determination, in National Water Well Association, Ground Water Geochemistry Conference, Denver, Colo., February 16-18, 1998, Proceedings: p. 339-359.

Yang, H.H., Vonopal, R.T., Grasso, Dominco, and Smets, B.F., 2004, High diversity among environmental Escherichia coli isolates from a bovine feedlot: Applied and Environmental Microbiology, v. 70, no. 3, p. 1528-1536. 


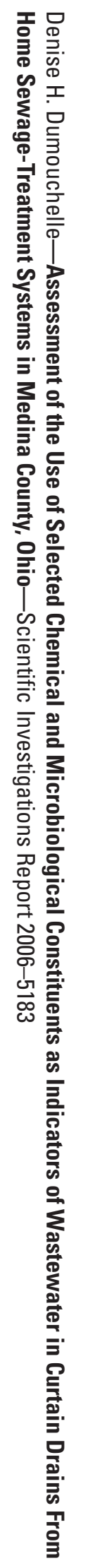

6 Printed on recycled paper 